University of Montana

ScholarWorks at University of Montana

$1-2007$

\title{
ASSESSING THE CARBON BALANCE OF CIRCUMPOLAR ARCTIC TUNDRA USING REMOTE SENSING AND PROCESS MODELING
}

\author{
Stephen Sitch
}

A. D. McGuire

John S. Kimball

University of Montana - Missoula

Nicola Gedney

J. A. Gamon

See next page for additional authors

Follow this and additional works at: https://scholarworks.umt.edu/ntsg_pubs

Let us know how access to this document benefits you.

\section{Recommended Citation}

Sitch, S., McGuire, A. D., Kimball, J., Gedney, N., Gamon, J., Engstrom, R., Wolf, A., Zhuang, Q., Clein, J. and McDonald, K. C. (2007), ASSESSING THE CARBON BALANCE OF CIRCUMPOLAR ARCTIC TUNDRA USING REMOTE SENSING AND PROCESS MODELING. Ecological Applications, 17: 213-234. doi:10.1890/ 1051-0761(2007)017[0213:ATCBOC]2.0.CO;2

This Article is brought to you for free and open access by the Numerical Terradynamic Simulation Group at ScholarWorks at University of Montana. It has been accepted for inclusion in Numerical Terradynamic Simulation Group Publications by an authorized administrator of ScholarWorks at University of Montana. For more information, please contact scholarworks@mso.umt.edu. 


\section{Authors}

Stephen Sitch, A. D. McGuire, John S. Kimball, Nicola Gedney, J. A. Gamon, Ryan Engstrom, Annett Wolf, Q. Zhuang, J. Clein, and Kyle C. McDonald 


\title{
ASSESSING THE CARBON BALANCE OF CIRCUMPOLAR ARCTIC TUNDRA USING REMOTE SENSING AND PROCESS MODELING
}

\author{
Stephen Sitch, ${ }^{1,11}$ A. David McGuire,${ }^{2}$ John Kimball, ${ }^{3}$ Nicola Gedney, ${ }^{4}$ John Gamon,,${ }^{5}$ Ryan Engstrom, ${ }^{6}$ \\ Annett Wolf, ${ }^{7,12}$ Qianlai Zhuang, ${ }^{8,13}$ Joy Clein, ${ }^{9}$ and Kyle C. McDonald ${ }^{10}$ \\ ${ }^{1}$ Potsdam Institute for Climate Impact Research (PIK), P.O. Box 601203, 14412 Potsdam, Germany \\ ${ }^{2}$ U.S. Geological Survey, Alaska Cooperative Fish and Wildlife Research Unit, 214 Irving I Building, University of Alaska, \\ Fairbanks, Alaska 99775 USA \\ ${ }^{3}$ Flathead Lake Biological Station, Division of Biological Sciences, 311 BioStation Lane, University of Montana, \\ Polson, Montana 59860-9659 USA \\ ${ }^{4}$ Met Office, Hadley Centre for Climate Prediction and Research (JCHMR), Maclean Building, Crowmarsh-Gifford, \\ Wallingford, $O X 108 B B, U K$ \\ ${ }^{5}$ Center for Environmental Analysis (CEA-CREST) and Department of Biological Sciences, 5151 State University Drive, \\ California State University, Los Angeles, California 90032 USA \\ ${ }^{6}$ Department of Geography, George Washington University, 1957 E Street NW, Suite 512, \\ Washington, D.C. 20052 USA \\ ${ }^{7}$ Abisko Scientific Research Station, 98107 Abisko, Sweden and Department of Physical Geography and Ecosystem Analysis, \\ Sölvegatan 12, Lund University, 22362 Lund, Sweden \\ ${ }^{8}$ The Ecosystems Center, Marine Biological Laboratory, 7 MBL Street, Woods Hole, Massachusetts 02543 USA \\ ${ }^{9}$ Institute of Arctic Biology, 214 Irving I Building, University of Alaska, Fairbanks, Alaska 99775 USA \\ ${ }^{10}$ Water and Carbon Cycles Group, Mail Stop 300-233, Jet Propulsion Laboratory, California Institute of Technology, \\ 4800 Oak Grove Drive, Pasadena, California 91109-8099 USA
}

Abstract. This paper reviews the current status of using remote sensing and process-based modeling approaches to assess the contemporary and future circumpolar carbon balance of Arctic tundra, including the exchange of both carbon dioxide and methane with the atmosphere. Analyses based on remote sensing approaches that use a 20-year data record of satellite data indicate that tundra is greening in the Arctic, suggesting an increase in photosynthetic activity and net primary production. Modeling studies generally simulate a small net carbon sink for the distribution of Arctic tundra, a result that is within the uncertainty range of field-based estimates of net carbon exchange. Applications of processbased approaches for scenarios of future climate change generally indicate net carbon sequestration in Arctic tundra as enhanced vegetation production exceeds simulated increases in decomposition. However, methane emissions are likely to increase dramatically, in response to rising soil temperatures, over the next century. Key uncertainties in the response of Arctic ecosystems to climate change include uncertainties in future fire regimes and uncertainties relating to changes in the soil environment. These include the response of soil decomposition and respiration to warming and deepening of the soil active layer, uncertainties in precipitation and potential soil drying, and distribution of wetlands. While there are numerous uncertainties in the projections of process-based models, they generally indicate that Arctic tundra will be a small sink for carbon over the next century and that methane emissions will increase considerably, which implies that exchange of greenhouse gases between the atmosphere and Arctic tundra ecosystems is likely to contribute to climate warming.

Key words: Arctic carbon cycle; biogeochemical cycles; carbon balance; carbon cycle modeling; highlatitude remote sensing; methane modeling; tundra.

Manuscript received 11 August 2004; revised 2 June 2005; accepted 6 June 2005; final version received 12 September 2005. Corresponding editor: M. L. Goulden.

${ }^{11}$ Present address: Met Office, Hadley Centre for Climate Prediction and Research (JCHMR) Maclean Building, Crowmarsh-Gifford, Wallingford, OX10 8BB, UK.

E-mail: stephen.sitch@metoffice.gov.uk

12 Present address: Department of Forest Ecology, Institute of terrestrial Ecosystems, CHN G 77, Universitätsstraße 16, 8092 Zurich, Switzerland.

13 Present address: Department of Earth and Atmospheric Sciences and Department of Agronomy, CIVIL, 550 Stadium Mall Drive, West Lafayette, Indiana 47907-2051 USA.

\section{INTRODUCTION}

The distribution of Arctic tundra is north of the northern hemisphere tree line, and covers $\sim 8 \%$ of the global land surface (McGuire et al. 1997). The exact location of its southern border is subjective, with the transition between closed forest and tundra up to several hundred kilometers wide in regions of low topographic relief (Vlassova 2002, Callaghan et al. 2005; Fig. 1).

Climate in the Arctic is harsh, characterized by cold winters and cool summers, with mean July temperatures below $\sim 12^{\circ} \mathrm{C}$ (Callaghan et al. 2005), and annual mean 
temperatures typically below $-10^{\circ} \mathrm{C}$ (New et al. 1999). Consequently, plant growth is restricted to a relatively short growing season on the order of three months or less during the summer months. The Arctic is home to $\sim 1800$ species of vascular plants and has less species diversity than more temperate biomes (Callaghan et al. 2005). In addition to vascular plant species, mosses and lichens play a very important role in the Arctic ecosystem structure and functioning. Frozen soils are prevalent in high latitudes with a north to south gradient from continuous to discontinuous permafrost. In general, Arctic tundra is underlain by continuous permafrost. The spatial and temporal dynamics of permafrost and periodic disturbance are crucial in shaping the Arctic landscape and its heterogeneity with important consequences for the areal extent of wetlands and the exchange of carbon dioxide $\left(\mathrm{CO}_{2}\right)$ and methane $\left(\mathrm{CH}_{4}\right)$.

High northern latitudes above $50^{\circ} \mathrm{N}$ contain $\sim 53 \%$ of the global wetland area (Aselmann and Crutzen 1989). In non-aerated waterlogged soils, anaerobic conditions drastically reduce microbial respiration rates, leading to accumulation of soil organic matter. With low ambient temperatures, waterlogged soils and slow drainage, these ecosystems have been slowly accumulating large stores of carbon over the last 6000 years (Malmer 1992). Wetlands are thought to be the single largest source of $\mathrm{CH}_{4}$, although the total anthropogenic source, primarily from rice agriculture, ruminants, and energy production, is larger (IPCC 2001). Methane is a much stronger greenhouse gas than $\mathrm{CO}_{2}$ on a molecular basis and currently contributes $\sim 20 \%$ of the radiative forcing of the anthropogenic well-mixed greenhouse gases. Despite this, relatively few studies (Friborg et al. 2003, Grant et al. 2003) address both $\mathrm{CO}_{2}$ and $\mathrm{CH}_{4}$ in the context of an ecosystem carbon balance. It is important to consider the responses of both of these gases to assess whether Arctic tundra will contribute to climate warming over the next century.

Future climate warming is predicted to be most pronounced over the Arctic, especially during winter and spring. High-northern-latitude winters are expected to warm between $1.3^{\circ} \mathrm{C}$ and $6.3^{\circ} \mathrm{C}$ by 2100 (IPCC 2001). Such changes will undoubtedly alter Arctic ecosystem structure and function. Continuing trends toward a warmer climate at high latitudes are expected to lead to a northward migration of tree line, longer growing seasons and increased vegetation productivity, thawing of permafrost and warming and deepening of the soil active layer with associated large changes in hydrology. There is increasing evidence that these changes are already occurring across large portions of the Arctic (Serreze et al. 2003, McDonald et al. 2004, Hinzman et al. 2005).

Any change in Arctic hydrology will impact not only the areal extent of wetlands, but also the exchange of both $\mathrm{CO}_{2}$ and $\mathrm{CH}_{4}$ (see Plate 1). Arctic ecosystems exist near the freezing point of water and are especially sensitive to climate change. Observed trends and current projections of regional warming thus have the potential to yield dramatic changes in hydrological processes, with associated increases in plant growth, soil nutrient mineralization, and decomposition. Although Arctic tundra has been estimated to contain only $6 \%$ of the total global terrestrial carbon stock (McGuire et al. 1997), the large and potentially volatile carbon pools currently stored in Arctic soils have the potential for large emissions of radiatively active greenhouse gases in the form of both $\mathrm{CO}_{2}$ and $\mathrm{CH}_{4}$ under warmer and potentially drier conditions, resulting in a positive feedback to global warming. Given the potential sensitivity of Arctic tundra to climate change and the expectation that the Arctic will experience appreciable warming over the next century, it is important to assess whether responses of ecosystem function and structure are likely to contribute or mitigate warming.

Information from remote sensing and modeling can complement ground-based observations, which are often difficult and expensive undertakings and necessarily of a limited spatial extent. Applications of spatially and temporally explicit models of land-atmosphere exchanges of $\mathrm{CO}_{2}$ and $\mathrm{CH}_{4}$ can be classified as either retrospective (i.e., historical applications) or prognostic (i.e., projections into the future). Retrospective analyses are conducted in order to diagnose temporal/spatial patterns and/or mechanisms responsible for the historical dynamics of $\mathrm{CO}_{2}$ and $\mathrm{CH}_{4}$ exchange. Models based on remote sensing are increasingly being used in retrospective analyses. These models generally attempt to assimilate satellite-based estimates of land surface variables (e.g., land cover type, leaf area index, absorbed photosynthetically active radiation) as major drivers of relatively simple models describing carbon dynamics in space and time (e.g., net photosynthesis, net primary production). In contrast, process-based models generally account for more detailed, interacting processes, and are more data and computationally intensive than remote sensing approaches, while their greater detail allows simulation of potential vegetation response to future conditions. This predictive capability allows processbased models to be used in assessing the responses of terrestrial ecosystems to scenarios of projected climate and disturbance, i.e., prognostic analyses, while applications of remote sensing approaches are limited to current conditions and retrospective analyses of historical conditions. The comparison of remote sensing and process-based approaches in retrospective analyses is valuable in that insights from remote sensing approaches can be used to improve process-based approaches for application in prognostic analyses. Because both remote sensing and process-based approaches are developed and evaluated with site-specific data on $\mathrm{CO}_{2}$ and $\mathrm{CH}_{4}$ exchange and with information on processes controlling the exchange of these gases, these approaches represent synthetic tools for assessing the current and future circumpolar carbon balance of Arctic tundra. 


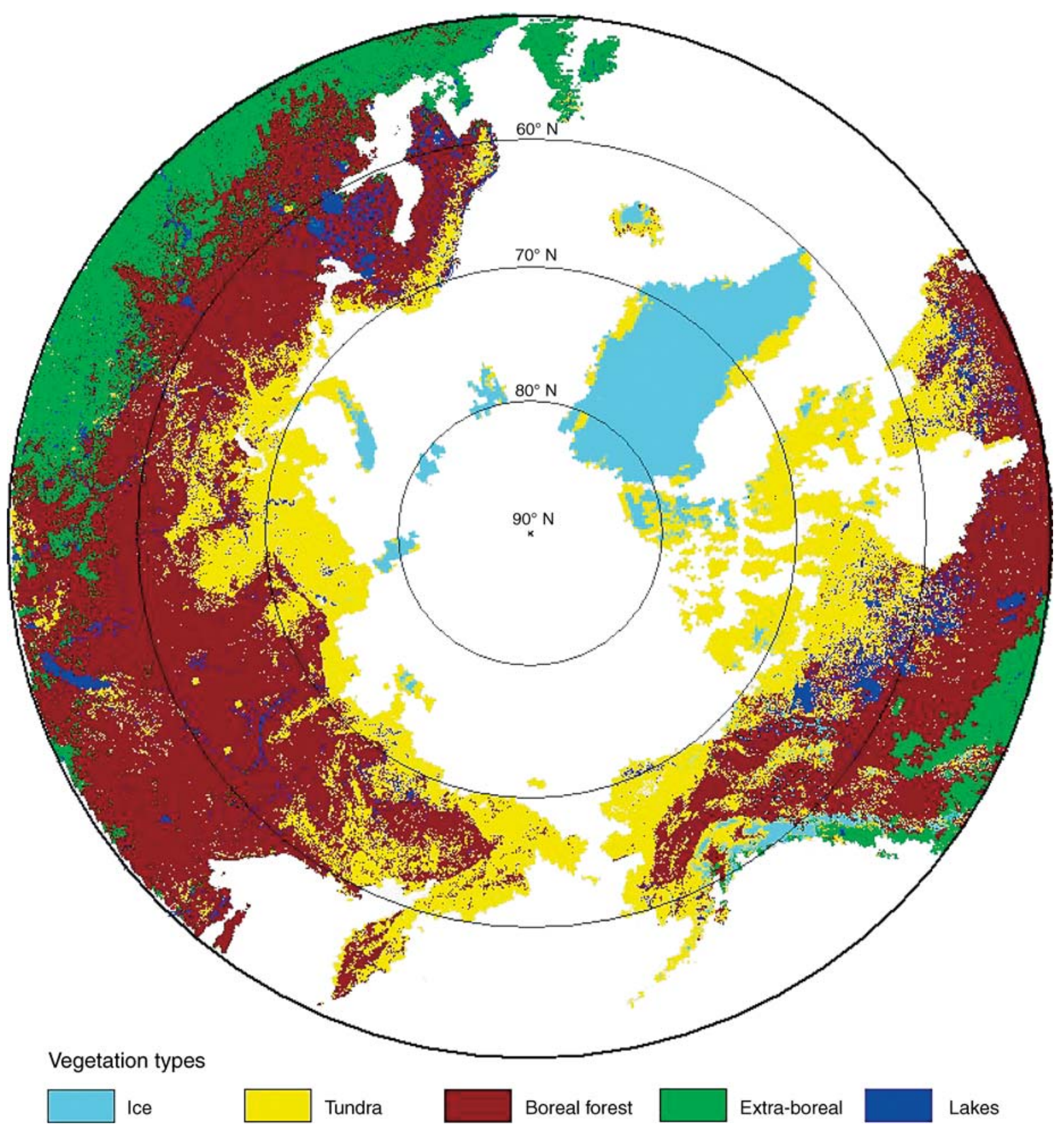

FIG. 1. Map of the Arctic and its vegetation types.

In this paper we review the remote sensing and process-based approaches that have been used to assess the current and future exchange of $\mathrm{CO}_{2}$ and $\mathrm{CH}_{4}$ between the atmosphere and Arctic tundra. We also report on the results of previous studies that have assessed the dynamics of $\mathrm{CO}_{2}$ and $\mathrm{CH}_{4}$ of Arctic tundra in retrospective analyses of historical climatic variability and change over the 20th century, and prognostic studies of projected climatic variability and change over the next century. We then discuss how these results compare with observational studies and the questions they raise about the role of various processes that may determine the potential response of Arctic tundra to future climate conditions.

\section{Modeling Approaches}

Applications of remote sensed data in carbon dioxide exchange modeling

Satellite remote sensing provides capabilities for regional mapping and monitoring of biophysical variables important for Arctic carbon cycle research, and at spatial and temporal scales that are generally inaccessible or impractical to field observations given resource, environmental, and geopolitical constraints. Whereas 
field observations give detailed insight into the structure and function of the local ecosystem, the ability to extrapolate such information in heterogeneous Arctic landscapes is limited. In general, remote sensing instruments were not designed to directly monitor the carbon cycle (although some prototype sensors now exist), but rather to detect land biosphere properties relevant to this cycle. Applications of satellite remote sensing used either directly or indirectly in high-latitude carbon cycle studies can be grouped into three general categories: (1) those directed at regional mapping of biophysical state variables such as land cover class (Gould et al. 2002, Walker et al. 2002), which can be used for initialization, calibration, and extrapolation of models (e.g., Soegaard et al. 2000); (2) empirical and process-oriented remote sensing algorithms linking spectral information such as the Normalized Difference Vegetation Index (NDVI) to more detailed ecosystem processes, such as phytomass (Walker et al. 2003), net primary production (Markon and Peterson 2002, Hope et al. 2003, Nemani et al. 2003), and net $\mathrm{CO}_{2}$ flux (Oechel et al. 2000b); (3) remote sensing detection of other physical and environmental parameters relevant to the carbon cycle, such as surface temperature (Comiso 2003), snow cover (Dye and Tucker 2003), landscape and soil freeze-thaw state (Kimball et al. 2001, Zhang and Armstrong 2001), growing-season timing and length (Kimball et al. 2004), vegetation greenness and phenology (Myneni et al. 1997, Zhou et al. 2001, 2003, Lucht et al. 2002), and fire disturbance (Boles and Verbyla 1999).

\section{Optical and near-infrared sensors}

Satellite remote sensing in visible and near-infrared wavelengths is sensitive to the energy absorbed by leaf chlorophyll (Markon and Peterson 2002, Zhou et al. 2003). This measure of land surface "greenness" is well correlated with leaf area, leaf biomass, and potential photosynthesis (Tucker 1979, Asrar et al. 1984, Tucker and Sellers 1986, Myneni et al. 1995, Zhou et al. 2003), and is therefore useful for biosphere studies of the spatial distribution of plants, their seasonal functioning, and for spatial extrapolation to regional and global scales. The most extensively used satellite products for pan-Arctic research are derived from optical and nearinfrared sensors such as the NOAA Advanced Very High Resolution Radiometer (AVHRR).

The global AVHRR time series is available from 1981 to the present with a spatial and temporal resolution of 8 $\mathrm{km}$ and 10-15 days, respectively (Zhou et al. 2001). Despite its original design for meteorological studies, AVHRR data provide a relatively continuous, long-term record of land surface characteristics relating to highlatitude terrestrial carbon budgets (e.g., Myneni et al. 1997, Zhou et al. 2001, Nemani et al. 2003). The moderate resolution imaging spectroradiometer (MODIS) onboard the NASA Terra and Aqua satellites was specifically designed for monitoring terrestrial vegetation and is equipped with enhanced spectral and spatial resolution, improved atmospheric correction, georeferencing and onboard calibration for global observations of vegetation conditions. MODIS represents an improvement over AVHRR in that it provides relatively stable, global observations at a $1-\mathrm{km}$ spatial resolution every 8 days from 2001 to the present (Running et al. 2000). The MODIS data stream also provides a relatively advanced suite of standardized variables for biospheric research including net photosynthesis and net primary production (NPP).

Despite recent advances in data processing and sensor technology, optical/near-infrared remote sensing is limited by frequent cloud cover, atmospheric aerosols, shadowing, and reduced solar illumination common to high-latitude environments. These limitations inhibit satellite capabilities for detecting subtle environmental trends and physical variations in carbon cycle dynamics at high latitudes. Previous investigations of long-term trends in the AVHRR record have shown evidence of recent advances in the onset of vegetation greening and the growing season at high latitudes (e.g., Myneni et al. 1997). However, the validity of these trends has been questioned because of the coarse 10-15 day temporal compositing of the data, atmospheric aerosol effects, problems with sensor and navigational drift, intercalibration of successive instruments, data contamination from volcanic eruptions, and bidirectional effects (e.g., Gutman and Ignatov 1995, Cihlar et al. 1998, Gutman 1999).

\section{Active and passive microwave sensors}

Satellite active and passive microwave remote sensing techniques are sensitive to landscape and vegetation structure, orientation, and dielectric properties associated with variable moisture content in plant biomass, soils, and snow cover (Ulaby et al. 1986). A variety of studies have been conducted in boreal and Arctic environments using satellite active and passive microwave remote sensing to assess spatial and temporal patterns of biophysical variables that may be affecting regional carbon cycles. These variables include surface soil moisture (Kane et al. 1996), snow cover (Armstrong and Brodzik 2001, Pulliainen and Hallikainen 2001), plant biomass (Ranson et al. 1997), land cover and wetlands classifications (Ranson and Sun 2000, Bowling et al. 2003), soil and surface freeze-thaw status (Kimball et al. 2001, Zhang and Armstrong 2001), and growingseason length (Frolking et al. 1999, Kimball et al. 2004). Unlike remote sensing at optical and near-infrared wavelengths, microwave remote sensing is generally sensitive to a greater volume of landscape vegetation, snow cover, and soil. The ability of microwave sensors to detect changes in the structure and moisture status of these various landscape components is strongly dependent on sensor wavelength, polarization, and spatial resolution, as well as landscape topography, vegetation structure, soil type, and the presence/absence and structure of snow cover. Longer wavelengths (e.g., 
L-band) are generally sensitive to a greater volume of surface vegetation and soil media, relative to shorter (Ku-, C-bands) wavelengths under similar conditions. These wavelengths are also largely independent of solar illumination, cloud cover, and other atmospheric attenuation impacts that can significantly degrade remote sensing capabilities at optical and infrared wavelengths. Regional assessment and monitoring capabilities from space-borne microwave remote sensing platforms largely depend on sensor design and orbital configuration and offer the potential for high-repeat, global mapping and regional monitoring under daynight and virtually all weather conditions.

While current satellite microwave sensors have the potential to resolve pan-Arctic carbon cycle trends with better temporal (i.e., daily) accuracy than existing optical and near infrared based satellite records, their ability to accurately resolve these trends at finer $(<25$ $\mathrm{km}$ ) spatial scales is less certain, particularly for topographically complex landscapes. The current limitations of these sensors generally involve trade-offs in achieving both high spatial and temporal fidelity. Current sensors such as SeaWinds and European Remote Sensing (ERS) scatterometers and Special Sensor Microwave/Imager (SSM/I) provide high-repeat (approximately daily) observations at high latitudes, but at relatively coarse $(25-50 \mathrm{~km})$ spatial scales, which limit capabilities for resolving sub-grid scale variability of individual landscape components. Synthetic Aperture Radars (SARs) such as Radarsat and ERS-1/2 provide finer $(3-200 \mathrm{~m})$ spatial resolutions, but with reduced (10-168 day) temporal fidelity. New satellite microwave platforms are currently under development to achieve both improved spectral and spatial characterization of Arctic environments (Entekhabi et al. 2004). Additional research is being conducted to integrate synergistic information from both optical/near-infrared and microwave sensors for improved regional monitoring.

\section{Process-based approaches to modeling carbon dioxide exchange}

A number of process-based models of tundra carbon dynamics have been applied to assess the response of $\mathrm{CO}_{2}$ exchange in Arctic tundra to climate variability and climate change. A few of these applications have been conducted at the pan-Arctic scale (Clein et al. 2000, McGuire et al. 2000a, Sitch et al. 2003, Callaghan et al. 2004, 2005), while other applications involve regional assessments in Alaska, USA (Clein et al. 2000, McGuire et al. 2000a, Stieglitz et al. 2000, Williams et al. 2000, 2001b, Le Dizès et al. 2003) and Russia (Zamolodchikov and Karelin 2001). There have also been a number of local-scale applications conducted at several Arctic sites in Alaska (McKane et al. 1997a, b. Hobbie et al. 1998, Clein et al. 2000, Grant et al. 2003, Van Wijk et al. 2003, Rastetter et al. 2004), the Zackenberg Valley in Greenland (Soegaard et al. 2000), and Svalbard, Norway (Lloyd 2001). The models used for assessing tundra carbon dynamics in these studies vary substantially in the degree of process representation and the applications of the models vary substantially in temporal and spatial resolution (Table 1).

Several models used to assess the dynamics of Arctic tundra have been specifically designed to enable parameterization and testing in the context of eddy covariance data. For example, the Soil-Plant-Atmosphere Model (SPA) of Williams et al. (1996, 2000, 2001a, b), the ecosys model of Grant (2001), and the model of Lloyd (2001) include a high degree of process description, and model flows of matter (e.g., carbon, water, and/or nitrogen) at a fine temporal resolution (i.e., half-hourly), while model results are typically evaluated over a period of several days up to one or more growing seasons. The SPA model has been temporally aggregated from sub-hourly to daily time resolution within the Aggregated Canopy Model (ACM; Williams et al. 1996), which has been applied to the Kuparuk River Basin of Alaska for examining spatial variability in gross primary production (GPP; Williams et al. 2001b) and the temporal variability of net $\mathrm{CO}_{2}$ exchange (Stieglitz et al. 2000). Ecosys (Grant 2001) has been used to evaluate interannual and longer term variability in carbon exchange $\left(\mathrm{CO}_{2}\right.$ and $\left.\mathrm{CH}_{4}\right)$ for coastal tundra at Barrow, Alaska (Grant et al. 2003), and the model of Lloyd (2001) to assess mechanisms driving interannual variability in carbon exchange for a high Arctic site on Svalbard, Norway.

Other models have been developed, parameterized, and tested, based on studies of experimental manipulations of water, light, nutrients, and carbon dioxide, e.g., the Marine Biological Laboratory General Ecosystem Model (MBL-GEM) and the Terrestrial Ecosystem Model (TEM), which have been primarily parameterized and tested using experimental manipulations from Long Term Ecological Research (LTER) investigations at Toolik Lake, Alaska. Applications of MBL-GEM include site-specific assessments for tussock tundra near Toolik Lake (McKane et al. 1997a, b, Hobbie et al. 1998, Clein et al. 2000, Le Dizès et al. 2003, Rastetter et al. 2004) and assessments for tundra in the Kuparuk River Basin in Alaska (Hobbie et al. 1998, Le Dizès et al. 2003). Applications of TEM include multi-scale assessments of Arctic tundra near Toolik Lake and the Kuparuk River Basin of Alaska and across the panArctic (Clein et al. 2000, McGuire et al. 2000a). Two models, TEM and the Lund-Potsdam-Jena Dynamic Global Vegetation Model (LPJ-DGVM; Sitch et al. 2003, Callaghan et al. 2004, 2005) have been used to assess the response of $\mathrm{CO}_{2}$ exchange for pan-Arctic ecosystems in the 21 st century.

Models developed to represent sub-hourly variation in carbon exchange primarily rely on interactions between air temperature, atmospheric humidity, soil moisture, photosynthetically active radiation, and wind speed to simulate atmospheric $\mathrm{CO}_{2}$ exchange (e.g., Williams et al. 1996). These models vary in complexity; some prescribe 
TABLE 1. Description of prognostic models applied over the Arctic.

\begin{tabular}{|c|c|c|c|}
\hline \multirow{2}{*}{$\begin{array}{l}\text { Literature citations } \\
\text { and model } \\
\text { characteristic }\end{array}$} & \multicolumn{3}{|c|}{ Model } \\
\hline & SPA & Ecosys & GEM \\
\hline \multicolumn{4}{|l|}{ Literature citations } \\
\hline Original model & Williams et al. (1996) & Grant (2001) & Rastetter et al. (1997) \\
\hline $\begin{array}{l}\text { Recent model applications } \\
\text { over Arctic ecosystems }\end{array}$ & $\begin{array}{l}\text { Williams et al. (2000), } \\
\text { Van Wijk et al. (2003) }\end{array}$ & Grant et al. (2003) & Le Dizès et al. (2003) \\
\hline \multicolumn{4}{|l|}{ Scale } \\
\hline \multicolumn{4}{|l|}{ Temporal } \\
\hline Resolution & $30 \mathrm{~min}$ & $60 \mathrm{~min}$ & annual \\
\hline Application & $\begin{array}{l}\text { diurnal to } \\
\text { multi-seasonal }\end{array}$ & $\begin{array}{l}\text { diurnal to multi-seasonal } \\
\text { (century application) }\end{array}$ & annual to century \\
\hline \multicolumn{4}{|l|}{ Spatial } \\
\hline Resolution & point & point & point \\
\hline Application & plot-regional & plot-regional & plot-regional \\
\hline \multicolumn{4}{|l|}{ Structure } \\
\hline Vegetation & diagnostic & diagnostic & diagnostic \\
\hline Litter/soil pools (no. pools) & no $(0)$ & yes (4) & yes (4) \\
\hline Microbial pools & no & yes & no \\
\hline \multicolumn{4}{|l|}{ Processes } \\
\hline \multicolumn{4}{|l|}{ General } \\
\hline Photosynthesis & $\begin{array}{l}\text { based on Farquhar and } \\
\text { von Caemmerer (1982) }\end{array}$ & $\begin{array}{l}\text { based on Farquhar } \\
\text { et al. (1980) }\end{array}$ & $\begin{array}{l}\text { based on Farquhar and } \\
\text { von Caemmerer (1982); } \\
\text { MBL-GEM III uses } \\
\text { photosynthesis module } \\
\text { from SPA }\end{array}$ \\
\hline $\begin{array}{l}\text { Heterotrophic } \\
\quad \text { respiration }\left(\mathrm{R}_{\mathrm{H}}\right)\end{array}$ & no & $\begin{array}{l}\text { dependent on substrate- } \\
\text { microbe complexes affected by } \\
\text { soil moisture and temperature } \\
\text { (Arrhenius function) }\end{array}$ & $\begin{array}{l}\text { dependent on soil carbon, } \\
\text { soil temperature, and } \\
\text { moisture; Rastetter } \\
\text { et al. (1997) }\end{array}$ \\
\hline Fire & no & no & no \\
\hline C:N dynamics & no (N parametrized) & yes & yes \\
\hline Energy flow & $\begin{array}{l}\text { yes, in Williams et al. } \\
\text { (2001a), Hinzman } \\
\text { et al. (1998) }\end{array}$ & yes & no \\
\hline \multicolumn{4}{|l|}{$\begin{array}{l}\text { Especially relevant } \\
\text { to Arctic ecosystems }\end{array}$} \\
\hline $\begin{array}{l}\text { Nonvascular plants } \\
\text { (mosses/lichens) }\end{array}$ & no & yes & no \\
\hline Permafrost & $\begin{array}{l}\text { yes, in Williams et al. (2001a), } \\
\text { Hinzman et al. (1998) }\end{array}$ & no & no \\
\hline Lateral hydrology & $\begin{array}{l}\text { yes, in Stieglitz } \\
\text { et al. }(2000)\end{array}$ & no & no \\
\hline Methane & no & yes & no \\
\hline
\end{tabular}

Notes: Abbreviations are: SPA, Soil-Plant-Atmosphere model; GEM, General Ecosystem Model; TEM, Terrestrial Ecosystem Model; LPJ, Lund-Potsdam-Jena Dynamic Global Vegetation Model; MBL-GEM, Marine Biological Laboratory General Ecosystem Model; GPP, gross primary production. "Yes"/"no" mean that a process or structure is included/not included in the model. A process that was either studied in depth separately from the original model description paper or included in a later study is denoted by "yes," followed by the relevant references.

certain critical variables such as canopy nitrogen for calculating photosynthesis and respiration processes (e.g., Lloyd 2001, Williams et al. 2000, 2001b, Stieglitz et al. 2000), while others attempt to dynamically simulate nitrogen (N) dynamics (Grant et al. 2003). Other models operate at coarser time scales such as monthly (e.g., TEM and LPJ-DGVM) and growingseason (e.g., MBL-GEM) intervals, and consider multiple constraints of temperature, water, light, and atmospheric $\mathrm{CO}_{2}$ on carbon sequestration through photosynthesis and the effects of temperature, soil moisture, and substrate quality on decomposition processes. Both TEM and MBL-GEM explicitly simu- late interactions between $\mathrm{C}$ and $\mathrm{N}$ cycling in ecosystems and limit carbon uptake by the vegetation based on the supply of nitrogen to meet the nitrogen requirement of building new tissue. While the LPJ-DGVM does not explicitly represent interactions between $\mathrm{C}$ and $\mathrm{N}$ dynamics, it does represent how competition among different plant functional types (e.g., herbaceous and woody vegetation) for water and light influence the composition of the vegetation. Thus, while there are many similarities among the models that have been used to assess the $\mathrm{CO}_{2}$ exchange of Arctic tundra, there is also substantial diversity in model representation of critical processes. 
TABle 1. Extended.

\begin{tabular}{ccc}
\hline \hline \multicolumn{2}{c}{ Model } \\
\hline TEM & LPJ \\
\hline
\end{tabular}

McGuire et al. (1992)

McGuire et al. $(2000 a, b)$

Sitch et al. (2003)

Callaghan et al. (2004, 2005)

month

seasonal to century

$0.5^{\circ}$

regional-global

diagnostic

yes (1)

no

GPP based on multiple limiting factors,

McGuire et al. (1997)

dependent on soil organic carbon, soil moisture, and air temperature; McGuire et al. (1997)

no

yes

no

$\begin{array}{lc}\text { no } & \text { no } \\ \begin{array}{l}\text { inclusion in study, Zhuang } \\ \text { et al. (2001, 2003) }\end{array} & \text { no } \\ \text { no } & \text { no } \\ \text { yes, in Zhuang et al. (2004) } & \text { no }\end{array}$

\section{Approaches to modeling methane exchange}

In spite of their importance to the global carbon cycle, there is considerable uncertainty in present-day estimates of $\mathrm{CH}_{4}$ emissions from Arctic wetlands. Process-based modeling of $\mathrm{CH}_{4}$ emissions use intensive, small-scale measurements for model development and calibration, followed by spatial and temporal extrapolations of model simulations using regional meteorological, vegetation, and topographic data as model inputs (Cao et al. 1996, Walter et al. 2001a, Gedney et al. 2004, Zhuang et al. 2004). In general, process-based approaches separate soils into an upper unsaturated zone and a lower saturated zone according to water table depth. Consumption of $\mathrm{CH}_{4}$, i.e., methanotrophy, occurs in the unsaturated zone, and production of $\mathrm{CH}_{4}$, i.e., methanogenesis, occurs in the saturated zone.
If the rate of methanogenesis is greater than the rate of methanotrophy, then methane is emitted from soils through diffusion. A number of environmental variables influence methanotrophy and methanogenesis in process-based models. Methanogenesis is often modeled as an anaerobic process that depends on carbon substrate availability, soil temperature, soil $\mathrm{pH}$, and redox potential. Methanotrophy is often modeled as an aerobic process that depends on soil $\mathrm{CH}_{4}$ concentration, soil temperature, soil moisture, and redox potential. In addition, methane transport through diffusion, plant-aided transport through hollow tubes, and the movement of bubbles through the water column (ebullition) may be represented in processbased models of $\mathrm{CH}_{4}$ exchange. These models are generally parameterized, calibrated, and verified/validated with data from site-specific studies of $\mathrm{CH}_{4}$ dynamics. Data from sites in Alaska (Toolik Lake, Bonanza Creek, Fairbanks) and the two North American BOREAS study areas were used in Zhuang et al. (2004). Walter et al. (2001a) used data from five sites including an Arctic tundra site in Alaska and two high-latitude sites in Scandinavia.

Extrapolation of process-based approaches relies on estimating the extent of wetlands using prescribed data sets of the fraction of the landscape that is inundated by wetlands. The hydrology of process-based approaches varies in sophistication. Some approaches explicitly consider the presence and absence of permafrost (e.g., Gedney and Cox 2003, Zhuang et al. 2004) in modeling water table depth and soil thermal dynamics. However, in some cases, the hydrology in process-based models of $\mathrm{CH}_{4}$ exchange is borrowed from land surface schemes of climate models that represent hydrology based on mineral soils. Recent improvements in the land surface schemes of climate models that are more appropriate for northern wetlands include explicit parameterization for peatlands (Letts et al. 2000) and the representation of nonvascular plants (Comer et al. 2000). Walter et al. (2001b) also highlight the need for including the effect of micro-topography on modeling water table heights. Most contemporary process-based models of $\mathrm{CH}_{4}$ exchange are not able to simulate how wetland extent responds to climate change. However, a new generation of process-based models that attempt to model the temporal and spatial dynamics of both wetland distribution and associated methane emissions are emerging (Kaplan 2002, Gedney and Cox 2003, Krinner 2003).

\section{Carbon Dioxide Exchange with the Atmosphere}

\section{Retrospective analyses by remote sensing approaches}

The long-term (since 1982) data record from the NOAA AVHRR suite of satellites indicates a general greening trend, longer growing seasons, and increased vegetation productivity for the mid to high latitudes, including the Arctic (Myneni et al. 1997, Zhou et al. 2001, Nemani et al. 2003). These records are generally 


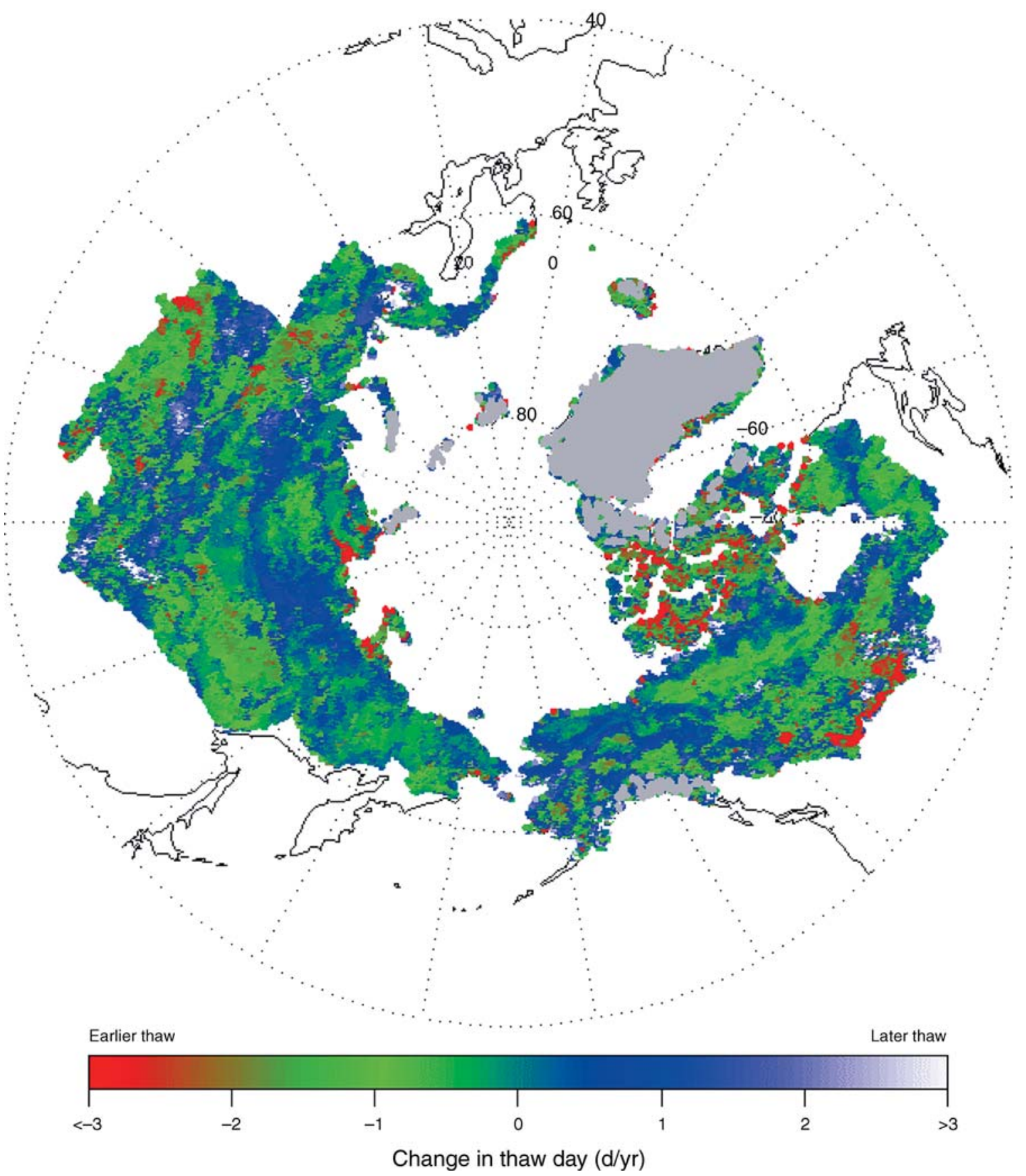

FIG. 2. Map of long-term (1988-2002) trends in the primary spring thaw day for the pan-Arctic basin and Alaska, USA, as derived from temporal change detection analysis of the daily SSM/I satellite record following the approach developed by McDonald et al. (2004). Masked areas are shown in gray and include permanent ice and snow, as well as barren and sparsely vegetated areas. Areas experiencing pronounced advance toward earlier thaw are indicated in red, while blue and white regions tend toward later thaw.

consistent with satellite microwave observations showing a regional trend towards earlier spring thaw and onset of the growing season (Fig. 2); decreased areal extent of snow cover and an earlier onset of seasonal snow melt (Groisman et al. 1994, Stone et al. 2002, Dye and Tucker 2003) for the pan-Arctic; and regional degradation of permafrost (Hinzman et al. 2001, Stow et al. 2004).

While these trends are derived from relatively coarse spatial scale (0.25-0.5 degree resolution) observations, other higher spatial resolution and longer term observations from aerial photographic records corrob- 

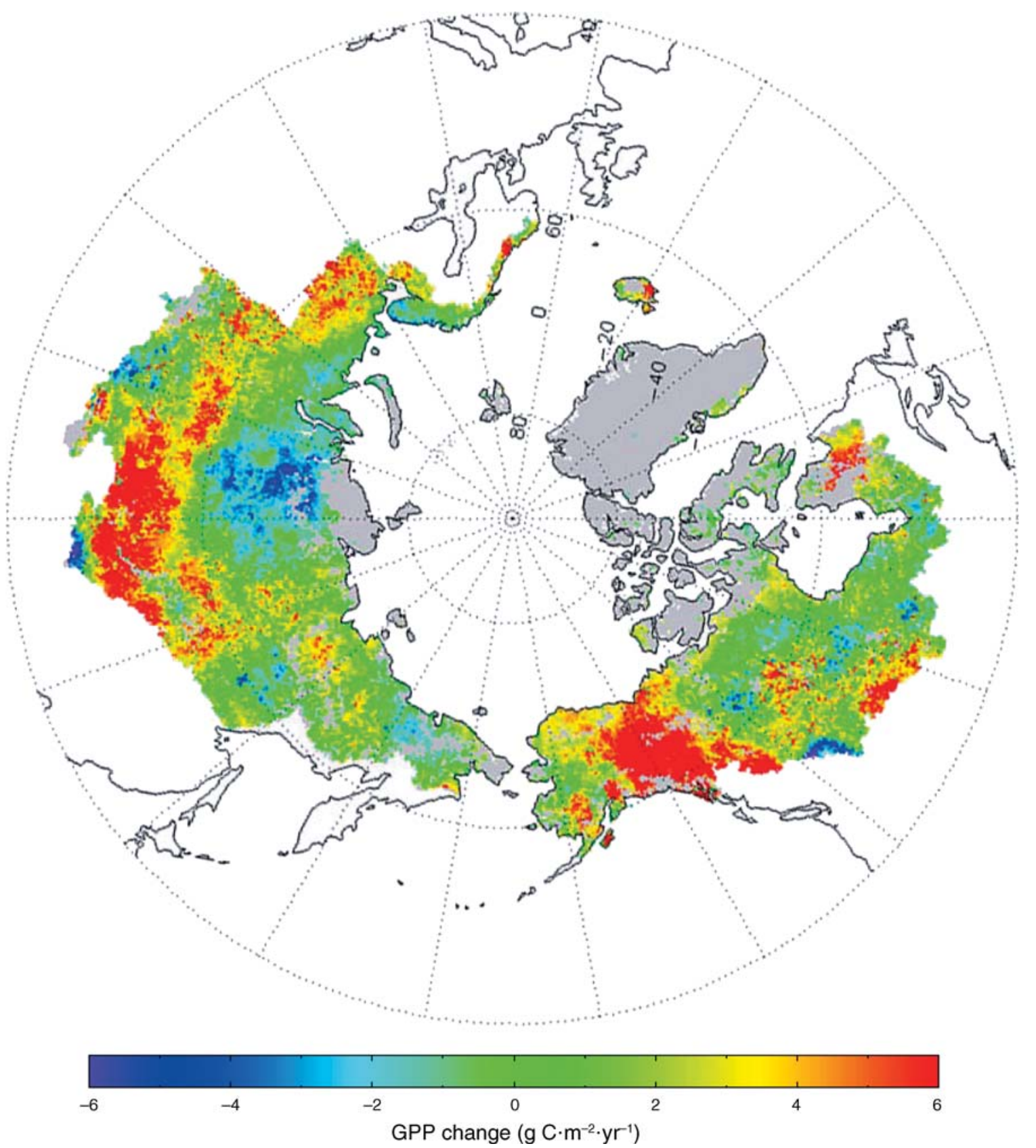

FIG. 3. Map of long-term (1982-2000) trends in annual gross primary production (GPP) for the pan-Arctic basin and Alaska as derived from the NOAA Advanced Very High Resolution Radiometer (AVHRR) Pathfinder record and a production efficiency model described by Nemani et al. (2003) and Running et al. (2004). Masked areas are shown in white and include permanent ice and snow and barren land, while large lakes and other water bodies are shown in blue. Overall trends for the region indicate increasing productivity (green areas), but with significant spatial and annual variability.

orate these results, showing a general increase in shrubs over the last 40 years in the Alaskan Arctic (Sturm et al. 2001, Stow et al. 2004). While the general trend in these observations indicates greening and higher productivity for the region, they also show considerable interannual and spatial variability, with many areas experiencing decreased greenness and lower productivity (Fig. 3).
Overall, these satellite observations indicate changes in aboveground vegetation activity and snow cover, but provide little information on belowground processes affecting soil carbon and nitrogen dynamics.

\section{Retrospective analyses of process-based approaches}

In general, retrospective analyses using process-based models of the land-atmosphere $\mathrm{CO}_{2}$ exchange for 


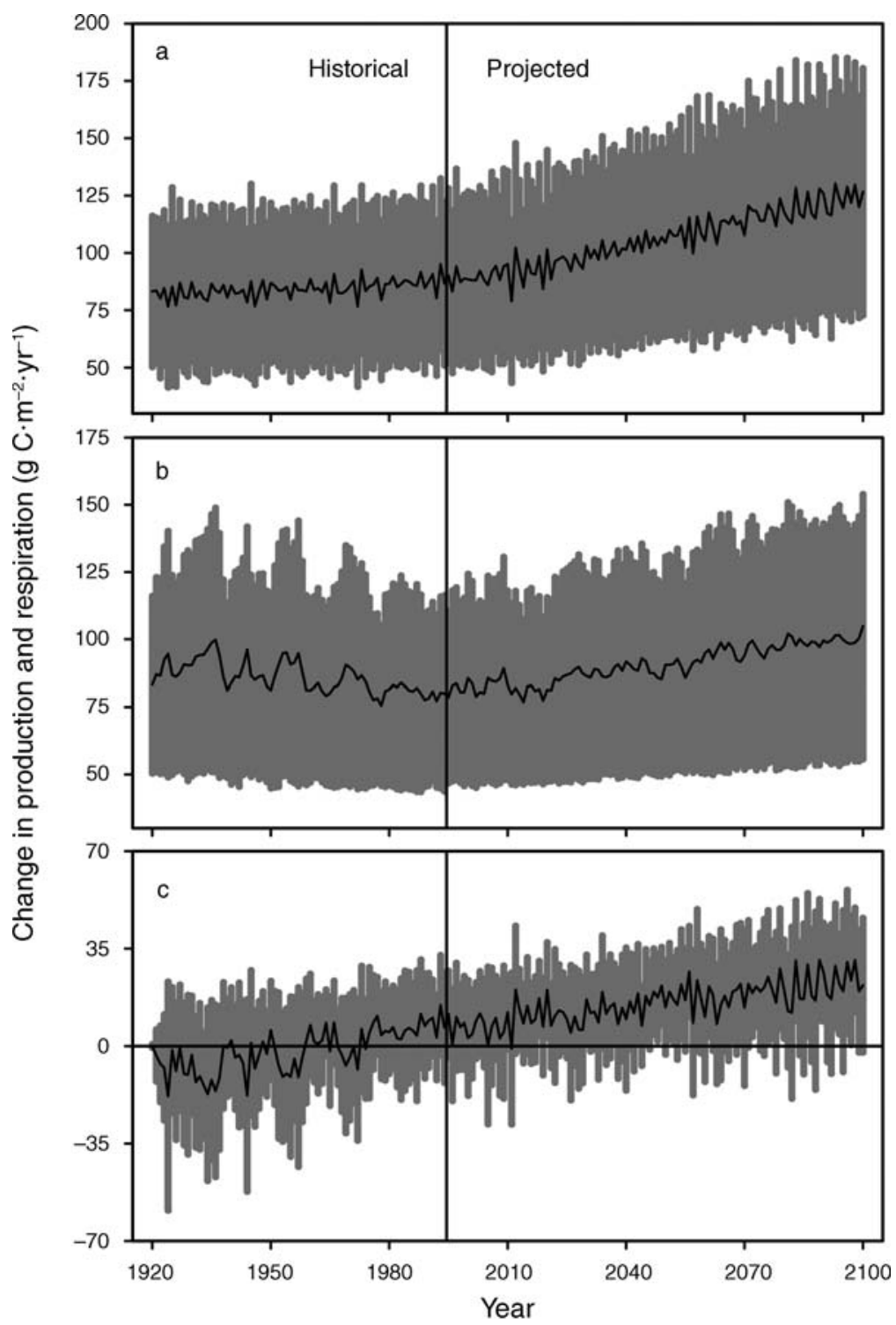

FIG. 4. Historical and projected changes in (a) net primary production, (b) heterotrophic respiration, and (c) net ecosystem production for the pan-Arctic as simulated by the Terrestrial Ecosystem Model (TEM) during the historical period (1921-1994) and projected period (1995-2100). The shaded region represents the standard deviation in carbon fluxes simulated by TEM across tundra of the pan-Arctic.

individual tundra locations and over the pan-Arctic domain of tundra ecosystems together suggest large interannual and spatial variability in historical sink vs. source activity (McKane et al. 1997b, Clein et al. 2000, McGuire et al. 2000a, Stieglitz et al. 2000, Lloyd 2001, Grant et al. 2003, Le Dizès et al. 2003, Sitch et al. 2003, Rastetter et al. 2004), with little net carbon storage in Arctic tundra ecosystems over the last century. For example, interannual variability of pan-Arctic tundra carbon dynamics over the last century as simulated by the TEM model of McGuire et al. (2000a) ranges from a net source of $18 \mathrm{~g} \mathrm{C} \cdot \mathrm{m}^{-2} \cdot \mathrm{yr}^{-1}$ to a sink of $16 \mathrm{~g}$ $\mathrm{C} \cdot \mathrm{m}^{-2} \cdot \mathrm{yr}^{-1}$ (2000) for atmospheric carbon. While these results indicate a long-term net loss from tundra ecosystems of only $1 \mathrm{~g} \mathrm{C} / \mathrm{m}^{2}$ over the last century, over the last 25 years, tundra ecosystems appear to have stored $\sim 10 \mathrm{~g} \mathrm{C} / \mathrm{m}^{2}$ of atmospheric carbon. The TEM simulation by McGuire et al. (2000a) is also characterized by substantial spatial variability in Arctic terrestrial carbon source-sink activity throughout the last century (Fig. 4; see also McGuire et al. 2000a: Fig. 9).

Among process-based models there are major differences in the sensitivities of terrestrial carbon exchange to climatic variability. To understand the importance of these sensitivities, it is important to examine responses at particular time scales.

Retrospective analyses of interannual variability differ in how plant carbon uptake, i.e., GPP or NPP, and 
carbon release from soils have responded to historical variation in temperature. Some analyses indicate that both $\mathrm{CO}_{2}$ uptake by vegetation and release by soils were highly correlated with interannual variability in temperature (McKane et al. 1997b, Stieglitz et al. 2000, Lloyd 2001, Grant et al. 2003, Le Dizès et al. 2003). Other analyses indicate that neither $\mathrm{CO}_{2}$ plant uptake nor release by soils were correlated with temperature (Clein et al. 2000, McGuire et al. 2000a). Instead, NPP was highly correlated with net nitrogen mineralization, and heterotrophic respiration $\left(\mathrm{R}_{\mathrm{H}}\right)$ was negatively correlated with soil moisture changes above field capacity (Clein et al. 2000, McGuire et al. 2000a).

The analysis of McKane et al. (1997b) is notable because it identified that, under assumed conditions of constant soil moisture, the relative sensitivities of NPP and $\mathrm{R}_{\mathrm{H}}$ responses to temperature changed between the 19 th and 20th centuries. This is a consequence of lower temperature optima for NPP than $\mathrm{R}_{\mathrm{H}}$ (Kane et al. 1997b). In the19th century, NPP was more sensitive to a unit change in temperature than $R_{H}$, while $R_{H}$ was more responsive in the 20th century, after a warmer climate had emerged from the Little Ice Age. In contrast, under conditions in which increased temperature was coupled with decreased soil moisture, the analyses of McKane et al. (1997b) indicate that the response of NPP was weakly correlated with temperature in comparison with the response of $\mathrm{R}_{\mathrm{H}}$. In general, analyses by process-based models agree that decreases in soil moisture lead to a net release of $\mathrm{CO}_{2}$ from increased aerobic respiration in tundra soils (McKane et al. 1997a, b. Clein et al. 2000, McGuire et al. 2000a, Stieglitz et al. 2000, Grant et al. 2003, Rastetter et al. 2004) as soils with moisture contents above field capacity become progressively more aerobic. While there is some disagreement about the relative sensitivities of NPP and $R_{H}$ to historical interannual variability in temperature, process-based models generally agree that plant uptake and decomposition will not decline with year-to-year increases in temperature. The models also agree that year-to-year declines in soil moisture will lead to increases in decomposition as long as soil moisture is above field capacity.

Interannual variability in summer precipitation and rainfall frequency may also play a role in interannual variability of $\mathrm{CO}_{2}$ exchange because mosses and lichens, which do not have vascular systems, must be wetted to effectively take up carbon through photosynthesis. Nonvascular plants in tundra ecosystems contribute substantially to annual uptake of carbon by the vegetation (Lloyd 2001, Grant et al. 2003). In the high Arctic, the modeling analysis of Lloyd (2001) revealed that differences in summer precipitation, and importantly, the frequency of rain events, explained, in part, interannual differences in growing-season net $\mathrm{CO}_{2}$ exchange because of differences in the photosynthetic response of nonvascular plants between summers with high vs. low precipitation. Photosynthesis of nonvascu- lar plants was positively correlated with summer rainfall frequency (Lloyd et al. 2001). The cause was the direct effect of plant moisture content on photosynthesis, and not an indirect effect of variable summer temperatures or light levels among years (Lloyd et al. 2001; C. R. Lloyd, personal communication).

For climatic variation on longer time scales, the responses of some models identify that other factors beyond the simple temperature sensitivities of plant uptake and decomposition may play a role in the response of carbon storage, e.g., in greater $\mathrm{CO}_{2}$ uptake by vegetation in response to a lengthening of the growing season (Van Wijk et al. 2003, also see Lloyd 2001). In other analyses, the long-term historical response of net carbon storage depends on interactions between soil and plant nitrogen cycling. Specifically, increased decomposition in response to increased temperature results in the mineralization of soil nitrogen, which, if taken up by plants, allows greater sequestration and storage of atmospheric carbon because photosynthesis and net primary production by tundra vegetation are generally nitrogen limited. Since plants have a higher $\mathrm{C}: \mathrm{N}$ ratio than soils, the transfer of $\mathrm{N}$ from soils to plants tends to lead to net carbon storage (Shaver et al. 1992, McKane et al. 1997b, Clein et al. 2000, McGuire et al. 2000a, Stieglitz et al. 2000, Le Dizès et al. 2003, Rastetter et al. 2004). This response can be greatly enhanced if there are shifts from herbaceous vegetation to shrubs because the allocation of carbon to woody tissue results in shrubs having a higher $\mathrm{C}: \mathrm{N}$ ratio than herbaceous plants (McKane et al. 1997b, Le Dizès et al. 2003, Rastetter et al. 2004). In some models, these interactions result in simulations where the temperature response of plant carbon uptake tends to be greater than the temperature response of decomposition (Clein et al. 2000). In other models there is a lag between decomposition and NPP that results in a short-term carbon loss from the system as an increase in temperature initially enhances decomposition more than NPP followed by a net carbon gain as NPP is enhanced more than decomposition (McKane et al. 1997b, Le Dizès et al. 2003). While the potential exists for warmer temperatures to substantially increase net carbon storage for Arctic tundra because of the interactions between soil and plant nitrogen dynamics, the capacity of plant uptake of newly available nitrogen to compensate for increases in decomposition depends on whether the additional nitrogen is retained by tundra ecosystems in a labile form (McGuire et al. 1992, McKane et al. 1997b, Stieglitz et al. 2000). Stieglitz et al. (2000) argue that historical carbon dynamics were reproduced only for the assumption that most of the nitrogen released by enhanced decomposition was retained by tundra ecosystems in a labile form.

\section{Prognostic applications of process-based approaches}

In general, prognostic simulations of process-based models under future climate scenarios for the $21 \mathrm{st}$ 


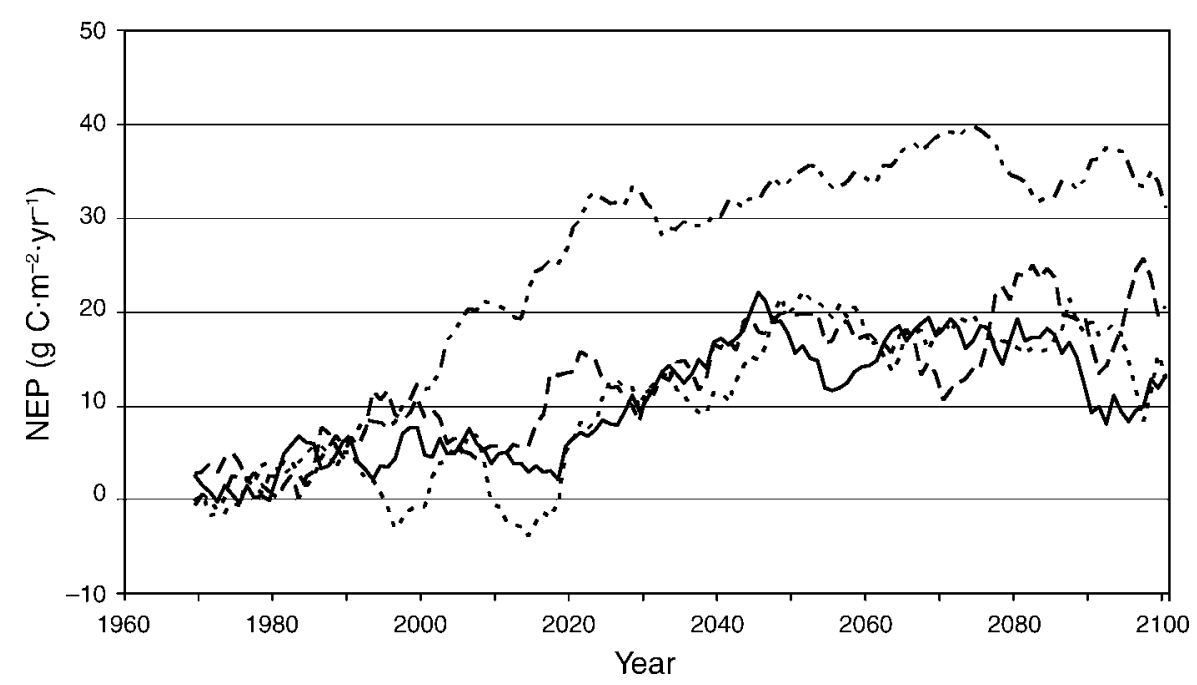

FIG. 5. Ten-year mean of future Arctic net ecosystem production (NEP) simulated by LPJ using climatologies from GFDL (dashed line), HadCM3 (solid line), CCC (dotted dashed line), and ECHAM3 (dotted line; see Table 2 for abbreviation explanations) for the emission scenario B2 of the Special Report on Emission Scenarios (SRES; see Callaghan et al. [2004, 2005] for circumpolar maps).

century indicate that both NPP and $\mathrm{R}_{\mathrm{H}}$ of tundra ecosystems will increase in response to projected climatic warming (Clein et al. 2000, McGuire et al. $2000 a$, Stieglitz et al. 2000, Grant et al. 2003, Le Dizès et al. 2003, Sitch et al. 2003, Rastetter et al. 2004). Most of these analyses indicate that tundra ecosystems will take up more atmospheric $\mathrm{CO}_{2}$ than they lose, resulting in a net increase in carbon storage for tundra ecosystems. Pan-Arctic model simulations show net increases in carbon storage ranging from $\sim 500$ to 3000 g C/m $\mathrm{m}^{2}$ over the 21st century (Clein et al. 2000, McGuire et al. 2000a, Sitch et al. 2003, Callaghan et al. 2004, 2005). Two exceptions are site-specific analyses of Stieglitz et al. (2000) and Grant et al. (2003), which estimate that enhanced uptake and release of $\mathrm{CO}_{2}$ will be approximately balanced during the 21 st century for tundra ecosystems at Toolik Lake, Alaska and Barrow, Alaska, respectively. Furthermore, the analysis of Grant et al. (2003) suggests that the long-term response of the Arctic terrestrial carbon budget depends on the rate of future climate warming, as temperature increases that are $50 \%$ greater than those for the IS92a scenario used in the study result in substantial estimated losses of soil carbon $\left(\sim 1000 \mathrm{~g} \mathrm{C} / \mathrm{m}^{2}\right)$ over the 21 st century. In contrast, the simulations with LPJ (Callaghan et al. 2004, 2005) indicate net carbon storage for the pan-Arctic over a range of projected climate scenarios (Fig. 5, Table 2). However, the prognostic simulations with ecosys (Grant et al. 2003) and LPJ (Sitch et al. 2003, Callaghan et al. 2004, 2005) are consistent in that the warmest scenario (ECHAM4) among the prognostic simulations of LPJ led to the lowest net carbon gain, while the coldest of the warming scenarios (CCC) led to highest carbon storage. Among LPJ simulations (Callaghan et al.
2004, 2005), the largest variation in response to climate change was in the soil carbon pools, indicating that the response of decomposition played an important role in the overall response of ecosystem carbon storage.

Similar to the retrospective analyses, prognostic simulations of tundra $\mathrm{CO}_{2}$ exchange by process-based models are characterized by substantial temporal and spatial variability. In contrast to the retrospective analysis of McGuire et al. (2000a), pan-Arctic NPP and $\mathrm{R}_{\mathrm{H}}$ are each strongly correlated with changes in temperature. Furthermore, in comparison with the retrospective analysis, the correlation of NPP with net nitrogen mineralization in the prognostic simulation is stronger, while the correlation of $\mathrm{R}_{\mathrm{H}}$ with changes in soil moisture is weaker. Besides identifying the potential for temporal differences in the response of fluxes (NPP and $\mathrm{R}_{\mathrm{H}}$ ) to changes in environmental variables, McGuire et al. (2000a) also analyzed their spatial variability in the prognostic simulations. First, there were substantial differences in the marginal response of NPP and $\mathrm{R}_{\mathrm{H}}$ to changes in temperature and soil moisture between moist tundra of the low arctic and polar desert of the high arctic. For example, the proportion of variation in NPP explained by temperature in polar desert is 0.63 in the mid-20th century, but drops to 0.44 in the late $21 \mathrm{st}$ century. In contrast, the marginal response of NPP to temperature in moist tundra differs little between the mid 20th century $\left(R^{2}=0.69\right)$ and the late 21 st century $\left(R^{2}=0.70\right)$. Second, a comparison of projected responses of moist-tundra carbon dynamics between simulations for the Kuparuk River Basin and pan-Arctic identified differences in the marginal response of fluxes to changes in temperature and soil moisture. For example, the proportion of variation in NPP explained by temperature at the pan-Arctic scale is 0.39 in the mid- 
TABLE 2. Mean and range in future projections of carbon storage and productivity changes, using the LPJ model (Sitch et al. 2003) run with climate scenarios from four different climate models (CCC, GFDL, HadCM3, ECHAM4) for the Arctic (see Callaghan et al. 2004, 2005).

\begin{tabular}{|c|c|c|}
\hline Characteristic & Mean & Range \\
\hline Temperature change $\left({ }^{\circ} \mathrm{C}\right)$ from 2100 to 2000 & +5.0 & +4.7 to +5.7 \\
\hline Precipitation change (mm/yr) from 2100 to 2000 & +43.0 & +9.0 to +78.0 \\
\hline \multicolumn{3}{|c|}{ Change in net primary production (NPP; $\mathrm{g} \mathrm{C} \mathrm{m}^{-2} \cdot \mathrm{yr}^{-1}$ ) } \\
\hline $\begin{array}{l}1960 \mathrm{~s} \\
2080 \mathrm{~s} \\
\text { Increase (\%) }\end{array}$ & $\begin{array}{l}+248 \\
+428 \\
+72\end{array}$ & $\begin{array}{c}+243 \text { to }+252 \\
+401 \text { to }+456 \\
+61 \text { to }+87\end{array}$ \\
\hline \multicolumn{3}{|l|}{ Change in $\mathrm{C}$ storage $\left(\mathrm{g} \mathrm{C} / \mathrm{m}^{2}\right)$ between 1960 and 2080} \\
\hline $\begin{array}{l}\text { Vegetation C } \\
\text { Soil C } \\
\text { Litter C } \\
\text { Total C }\end{array}$ & $\begin{array}{l}+503 \\
+613 \\
+494 \\
+1609\end{array}$ & $\begin{array}{l}+316 \text { to }+671 \\
+141 \text { to }+1372 \\
+300 \text { to }+843 \\
+1071 \text { to }+2750\end{array}$ \\
\hline \multicolumn{3}{|l|}{ Arial vegetation change between 1960 and 2080 (\%) } \\
\hline Taiga vs. tundra from 2080 to $1960 \dagger$ & +11.3 & +9.8 to +14.4 \\
\hline Polar desert vs. tundra from 2080 to $1960 \dagger$ & -17.6 & -23.0 to -14.2 \\
\hline
\end{tabular}

Note: Abbreviations of general circulation models (GCMs) are: CCC, Canadian Centre Climate; GFDL, Geophysical Fluid Dynamics Laboratory; HadCM3, Hadley Centre Coupled Model; ECHAM4, European Centre Hamburg Model.

$\dagger$ LPJ-simulated spatial coverages of several woody and herbaceous plant functional types across the domain of the pan-Arctic. These coverages were aggregated into three biomes: taiga, tundra, and polar desert. This table presents the change in areal extent of the three biomes, expressed in terms of a percentage of the total Arctic land area.

20th century, but drops to 0.32 in the late 21 st century. In contrast, the marginal response of NPP to temperature in Kuparuk River Basin differs little between the mid-20th century $\left(R^{2}=0.89\right)$ and the late 21 st century $\left(R^{2}=0.91\right)$. The variable results of the analysis of spatial variability in the sensitivity of carbon dynamics to changes in environmental variables caution against simple extrapolations of analyses for individual sites or restricted regions to the entire domain of pan-Arctic tundra.

Similar to retrospective analyses, the importance of different mechanisms responsible for increases in carbon uptake and decomposition in prognostic simulations vary among analyses. While the climate change analysis of Van Wijk et al. (2003) indicates that tundra GPP will generally increase with warmer temperatures and earlier onset and lengthening of the growing season, the degree of GPP response largely depends on the onset of the end of the growing season. If the appearance of frost regulates the end of growing season, the analysis of Van Wijk et al. (2003) indicates that a warming of $3^{\circ} \mathrm{C}$ could increase GPP by $30 \%$ in tussock tundra compared with a 10\% increase if the onset of the end of the growing season is regulated by photoperiod. While lengthening of the growing season also contributed to increased seasonal photosynthesis of most of the prognostic analyses, increases in NPP are primarily associated with the transfer of soil nitrogen to vegetation with higher C:N ratios (Clein et al. 2000, McGuire et al. $2000 a$, Stieglitz et al. 2000, Grant et al. 2003, Le Dizès et al. 2003, Rastetter et al. 2004). In the simulations conducted by Le Dizès et al. (2003), the role of changes in the $\mathrm{C}: \mathrm{N}$ ratio of tundra vegetation, i.e., a shift from herbaceous vegetation to shrubs, contributed more to the increase in NPP by the end of the 21st century than the transfer of $\mathrm{N}$ from soil to vegetation only for the application of a wet scenario. For most models that explicitly consider $\mathrm{C}-\mathrm{N}$ interactions, the response of NPP to increases in atmospheric $\mathrm{CO}_{2}$ is minimal because vegetation production is generally limited by nitrogen availability. However, in some of the models, the C:N ratio of vegetation increases slightly in response to increasing atmospheric $\mathrm{CO}_{2}$ and explains some of the increased carbon storage (Clein et al. 2000, McGuire et al. 2000a, Le Dizès et al. 2003, Rastetter et al. 2004, see also McGuire et al. 1997). Although LPJ (Sitch et al. 2003; Fig. 5) does not explicitly consider $\mathrm{C}-\mathrm{N}$ interactions, an increase in woody vegetation is primarily responsible for increases in carbon storage simulated for the pan-Arctic. For LPJ, 55\% of the average net carbon storage among future climate scenario simulations is associated with future increases in atmospheric $\mathrm{CO}_{2}$.

While prognostic model simulations generally agree that increases in temperature will lead to increases in decomposition, the sensitivity of decomposition response varies among the models and depends substantially on how soil moisture responds to changes in temperature and precipitation (Clein et al. 2000, McGuire et al. 2000a, Sitch et al. 2003, Callaghan et al. 2004, 2005). Another important issue in the response of decomposition concerns the representation of labile vs. recalcitrant soil organic matter (Clein et al. 2000). If most of the $R_{H}$ flux is derived from $C$ derived from recent photosynthetic activity, i.e., labile soil organic matter, then the response of $R_{H}$ to changes in temperature has the potential to track the response of 

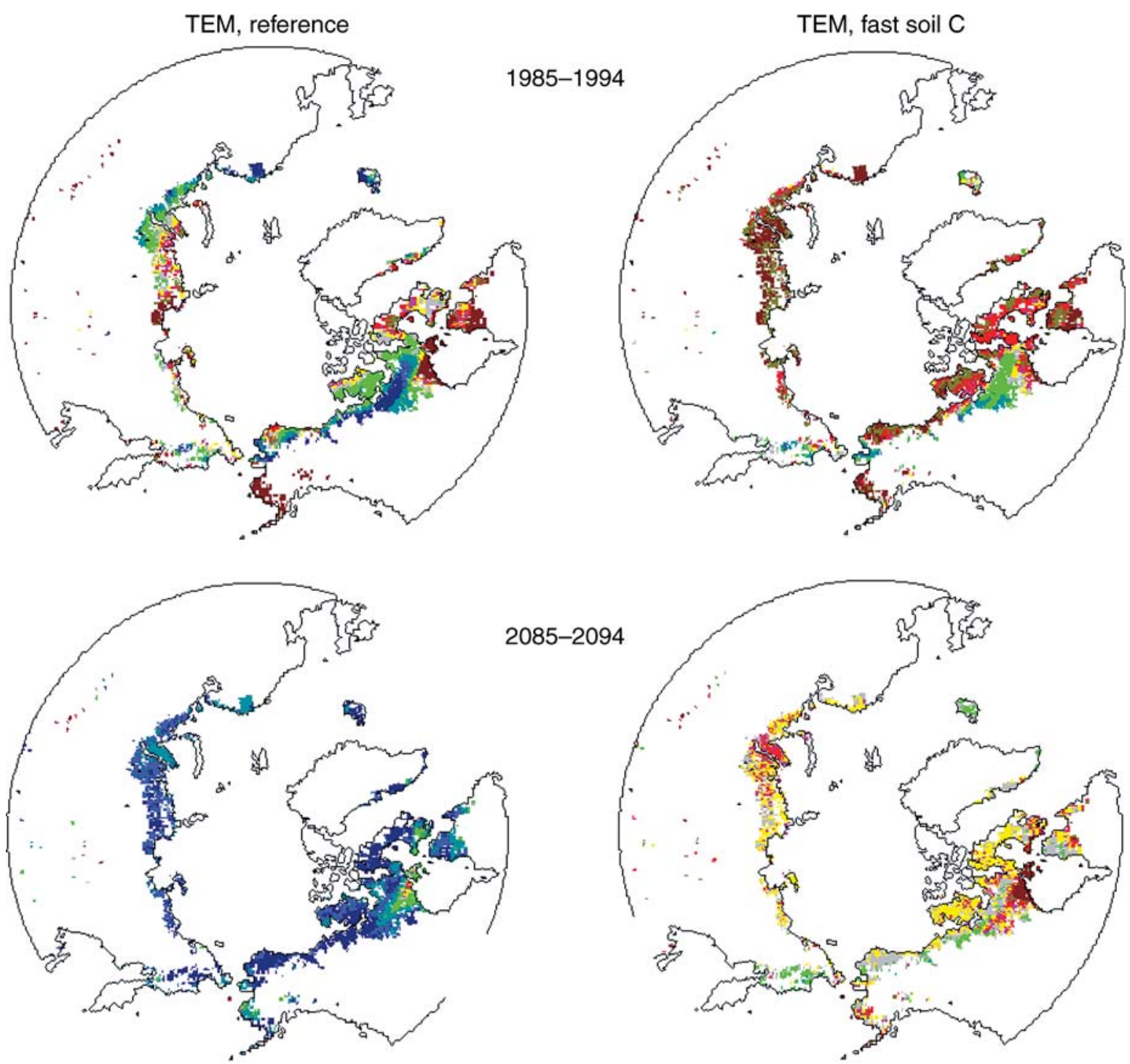

$\operatorname{NEP}\left(\mathrm{g} \mathrm{C}^{-2} \mathrm{~m}^{-2} \cdot \mathrm{yr}^{-1}\right)$
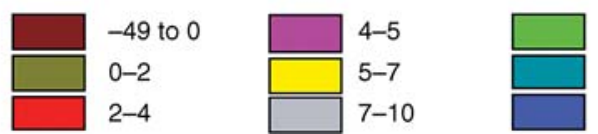

$10-19$
$19-28$
$28-31$

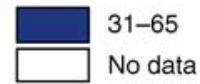

FIG. 6. Simulated spatial and temporal variability in mean annual NEP in moist tundra ecosystems north of $50^{\circ} \mathrm{N}$ for the decades from 1985 to 1994 and from 2085 to 2094 as simulated by the Terrestrial Ecosystem Model (TEM) with the reference parameterization and by TEM for fast soil $\mathrm{C}$ dynamics (i.e., with much faster soil carbon turnover in comparison with the reference parameterization; Fig. 10 of Clein et al. 2000).

NPP. In contrast, if a substantial portion of the $R_{H}$ is derived from recalcitrant pools, then the response of $R_{H}$ will lag increases in NPP and tend to increase $\mathrm{C}$ storage. The alternative representations of different patterns of $\mathrm{C}$ cycling in tundra soils result in greater differences in simulated $\mathrm{C}$ storage for the pan-Arctic between the end of the 20th and 21st centuries (Fig. 6).

\section{Methane Exchange with the Atmosphere}

Global estimated $\mathrm{CH}_{4}$ emissions from terrestrial soils range from 150 to $250 \mathrm{Tg} \mathrm{CH}_{4} / \mathrm{yr}$ under contemporary climate conditions (Prather et al. 2001). Studies that estimate high-latitude $\mathrm{CH}_{4}$ emissions rarely separate boreal forest from tundra, but estimates for wetlands north of $45^{\circ} \mathrm{N}$ range from 31 to $106 \mathrm{Tg} \mathrm{CH}_{4} / \mathrm{yr}$ among 


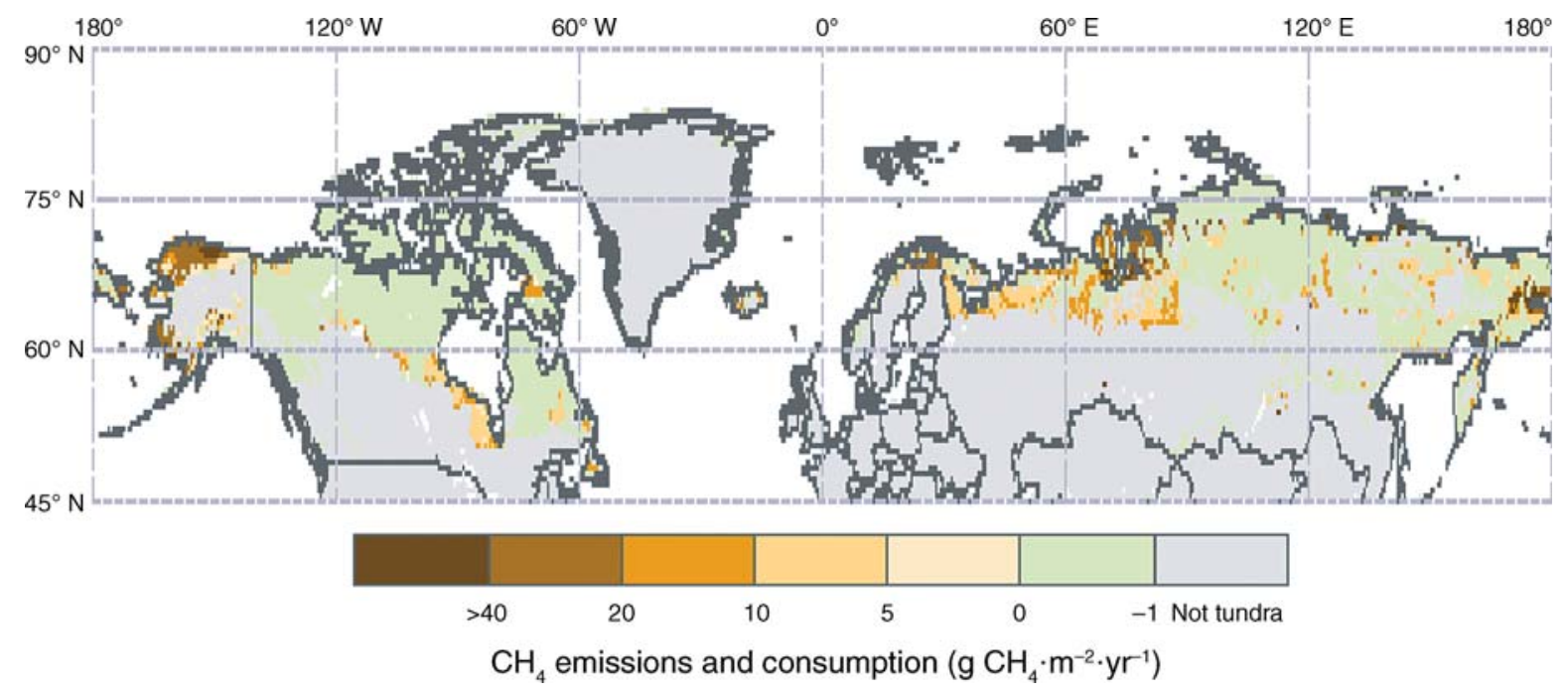

FIG. 7. Simulated net $\mathrm{CH}_{4}$ emissions and consumption in tundra ecosystems in the pan-Arctic region ( $45^{\circ} \mathrm{N}$ and above) during the 1990s. Positive values indicate the net $\mathrm{CH}_{4}$ release to the atmosphere, and negative values indicate the $\mathrm{CH}_{4}$ uptake from the atmosphere.

12 studies (see Table 3 of Zhuang et al. 2004). The study of Zhuang et al. (2004), which used a process-based model to conduct a retrospective analysis of $\mathrm{CH}_{4}$ dynamics for terrestrial ecosystems north of $45^{\circ} \mathrm{N}$, estimated annual net emissions of $51 \mathrm{Tg} \mathrm{CH}_{4} / \mathrm{yr}$ for this region at the end of the 20th century, with $57 \mathrm{Tg} \mathrm{CH}_{4} / \mathrm{yr}$ being emitted from soils and $6 \mathrm{Tg} \mathrm{CH}_{4} / \mathrm{yr}$ being consumed by soils. Russia, Canada, and Alaska were major regional sources of $\mathrm{CH}_{4}$ to the atmosphere, being responsible for $64 \%, 11 \%$, and $7 \%$ of the simulated net emissions, respectively, with the remaining $18 \%$ from other land mass north of $45^{\circ} \mathrm{N}$ (e.g., Scandinavia, Eastern Europe). Tundra ecosystems are estimated to account for emissions of $21 \mathrm{Tg} \mathrm{CH}_{4} / \mathrm{yr}$ for tundra north of $45^{\circ} \mathrm{N}$ during the $1990 \mathrm{~s}$ (Fig. 7). Similar to retrospective analyses of $\mathrm{CO}_{2}$ exchange with the atmosphere, the simulations of Zhuang et al. (2004) indicate large interannual variability in the magnitude of $\mathrm{CH}_{4}$ emissions of Arctic tundra over the 20th century in response to interannual climate variability. Estimated emissions range from $13-30 \mathrm{Tg} \mathrm{CH}_{4} / \mathrm{yr}$ over the 20th century for tundra ecosystems. The study by Zhuang et al. (2004) estimates that annual methane emissions of high-latitude ecosystems have increased at a rate of 0.08 $\mathrm{Tg} \mathrm{CH} / \mathrm{yr}$ over the 20th century, and more substantially in recent decades $\left(\sim 1 \mathrm{Tg} \mathrm{CH} \mathrm{CH}_{4} \cdot \mathrm{yr}^{-1} \cdot \mathrm{yr}^{-1}\right.$ in the 1980s), which is consistent with observed changes in atmospheric $\mathrm{CH}_{4}$ concentrations. Results suggest that changes in climate, with increases in mean annual temperature and precipitation, over the 20th century led to enhanced plant production (and increased root exudates for methanogenesis) and changes in the soil environment which together resulted in enhanced $\mathrm{CH}_{4}$ emissions (Table 6; Zhuang et al. 2004). An increase in natural $\mathrm{CH}_{4}$ emissions can only partly explain the increase in atmospheric $\mathrm{CH}_{4}$ concentrations. Atmospheric concentrations are influenced by a variety of factors, including atmospheric transport, atmospheric $\mathrm{CH}_{4}$ oxidation, and anthropogenic emissions, which have increased during this period (Zhuang et al. 2004). Decadal-scale variation in simulated net emissions of $\mathrm{CH}_{4}$ is more highly correlated with decadal variation temperature than precipitation. This is in agreement with a global atmospheric inversion analysis (Gedney et al. 2004), which suggests that temperature (not precipitation) is the dominant driver of interannual variability in global wetland $\mathrm{CH}_{4}$ flux in the recent past. Thus, the retrospective analysis of sensitivity of $\mathrm{CH}_{4}$ emissions to historical climate variability indicate that $\mathrm{CH}_{4}$ emissions may be very sensitive to temperature, and suggests that increases in temperature are likely to increase net $\mathrm{CH}_{4}$ emissions from northern wetlands.

Cao et al. (1998) predict that, under a scenario of modest warming $\left(+1^{\circ} \mathrm{C}\right)$ of mean annual temperatures and no change in soil water, northern wetland $\mathrm{CH}_{4}$ emissions are enhanced up to $45 \%$. However, if the effect of temperature on evaporation and, thus, soil moisture is included, then a temperature increase $>2^{\circ} \mathrm{C}$ would result in a reduction in net $\mathrm{CH}_{4}$ emissions. An increase in temperature and precipitation of $2^{\circ} \mathrm{C}$ and $10 \%$, respectively, produces a $20 \%$ increase in northern wetland $\mathrm{CH}_{4}$ emissions. These results demonstrate the critical interaction between temperature and soil moisture in regulating methane emissions for tundra ecosystems.

Using a process-based model that was calibrated from present-day atmospheric $\mathrm{CH}_{4}$ variability, Gedney et al. (2004) predicted increases in global $\mathrm{CH}_{4}$ flux between present-day and 2100 of $\sim 75 \%$ under the IS92A scenario (the radiative feedback of enhanced wetland 

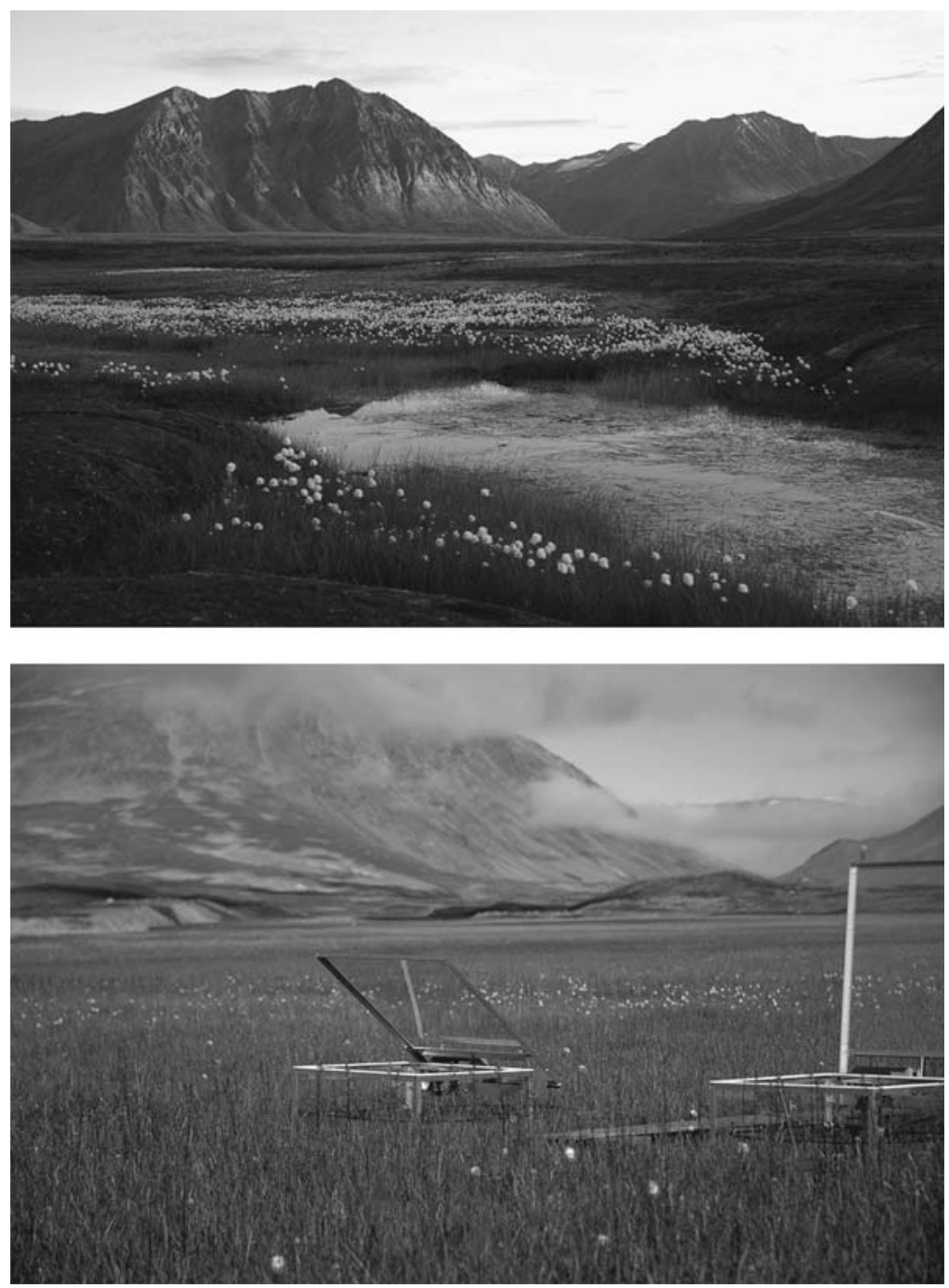

Plate 1. (Top) Dense cover of Eriophorum spp. filling in a thermokarst erosion pond and (bottom) automatic chambers monitoring $\mathrm{CO}_{2}$ and $\mathrm{CH}_{4}$ exchanges in a tundra fen. Both photos were taken in Zackenberg Valley, northeast Greenland, a hotspot for both $\mathrm{CO}_{2}$ exchange and $\mathrm{CH}_{4}$ emissions. Photo credits: Torben R. Christensen.

$\mathrm{CH}_{4}$ emissions are included in this simulation). The corresponding emissions from nontropical $\left(>30^{\circ} \mathrm{N}\right)$ northern wetlands increase by $\sim 100 \%$ (e.g., $44-84 \mathrm{Tg}$ $\mathrm{CH}_{4} / \mathrm{yr}$ in one set of simulation ensembles). These results occur despite an estimated $\sim 10 \%$ reduction in northern wetland areal extent. The overall pattern of change in high-latitude wetland extent is not geographically uniform, however, but appears very dependant on the regional extent of current and predicted future permafrost.

The application of process-based models to estimate responses of $\mathrm{CH}_{4}$ exchange to climate change for highlatitude ecosystems indicate that $\mathrm{CH}_{4}$ emissions from wetland soils will be enhanced more than $\mathrm{CH}_{4}$ consumption by upland tundra soils. For example, the study of Zhuang et al. (2007) indicates that $\mathrm{CH}_{4}$ emissions from ecosystems in Alaska have the potential to double by the end of the 21st century. Sensitivity analyses of $\mathrm{CH}_{4}$ emissions from wetlands conducted by Zhuang et al. (2007) indicate that a $2^{\circ} \mathrm{C}$ average temperature increase has the potential to stimulate $\mathrm{CH}_{4}$ production and hence enhance $\mathrm{CH}_{4}$ emissions by $30 \%$. This represents a much larger response than the estimated $20 \%$ increase in $\mathrm{CH}_{4}$ emissions associated with a projected $10 \mathrm{~mm}$ rise in the water table. Results of a sensitivity analysis also demonstrate a linkage between $\mathrm{CO}_{2}$ uptake by vegetation and $\mathrm{CH}_{4}$ emissions, as an estimated $20 \%$ increase in NPP leads to an $8 \%$ increase in methane emissions. The simulations of Zhuang et al. (2007) for Alaska indicate that methane emissions of 3 $\mathrm{Tg} \mathrm{CH}_{4} / \mathrm{yr}$ by year 2000 increased at an annual rate of $0.026 \mathrm{Tg} \mathrm{CH}_{4} / \mathrm{yr}$ over the 21 st century. This simulated increase in $\mathrm{CH}_{4}$ emissions is primarily explained by the temperature sensitivity of methanogenesis, and second- 
arily by the increase in NPP of Alaskan ecosystems simulated for the 21st century, in total outweighing the effects of an average annual drop in the water table of $0.1 \mathrm{~mm} / \mathrm{yr}$. The sensitivity to temperature at the regional scale is consistent with a site specific prognostic simulation of $\mathrm{CH}_{4}$ emissions at Barrow, Alaska, by Grant et al. (2003), which predicted that $\mathrm{CH}_{4}$ emissions would double by the end of the 21st century for a temperature increase under an IS92a projected climate scenario, and would triple for a temperature increase of 1.5 times the IS92a scenario.

\section{DisCUSSION}

A growing body of evidence indicates that the Arctic is becoming warmer (Chapman and Walsh 1993) and drier (Oechel et al. 1993, Serreze et al. 2000). Long-term satellite and aerial remote sensing observations of a greening Arctic indicate a regional response of increasing vegetation productivity and accelerated sequestration and storage of atmospheric $\mathrm{CO}_{2}$ by tundra vegetation (Myneni et al. 1997, Sturm et al. 2001, Nemani et al. 2003). Increasing vegetation productivity may be a direct response to a warming climate (i.e., more favorable temperatures for photosynthesis and longer growing seasons), as well as an indirect response to increased soil decomposition and respiration processes and an accelerating nitrogen cycle. Of particular concern is the response of tundra soil carbon pools to warming climate (Lal and Kimble 2000). Models are important tools that synthesize information from observation and process studies and can be used to assess the vulnerability of tundra carbon storage to climatic variability and change.

Taken together, retrospective analyses of remote sensing and process-based models suggest that Arctic tundra is currently either a small sink or a small source of atmospheric $\mathrm{CO}_{2}$ and that there is substantial interannual and spatial variability in the exchange of $\mathrm{CO}_{2}$. The applications of both remote sensing and process-based approaches generally agree that NPP of Arctic tundra has increased in response to rising temperature during the last several decades, leading to greater storage of carbon in vegetation carbon pools and greater inputs of carbon into the soils of Arctic ecosystems. While the models generally agree that $R_{H}$ is also increasing in response to rising temperature in recent decades, there is variability among the models as to whether $R_{H}$ is keeping pace with NPP or $R_{H}$ is lagging NPP. Some of the models indicate that there is the potential for $R_{H}$ to increase more than NPP in response to a sudden rise in temperature in the short term, but that interactions between $\mathrm{C}$ and $\mathrm{N}$ dynamics cause NPP to increase more than $\mathrm{R}_{\mathrm{H}}$ as $\mathrm{N}$ is transferred to vegetation as additional biomass and leaf area, and as the composition tundra changes from herbaceous vegetation to shrubs with a larger $\mathrm{C}: \mathrm{N}$ ratio in response to changes in climate and atmospheric $\mathrm{CO}_{2}$.
The responses of NPP and $\mathrm{R}_{\mathrm{H}}$ during the last several decades are generally consistent with several observational studies. Increases in NPP simulated by processbased models over the last several decades are consistent with several remote sensing analyses based on NDVI trends (Myneni et al. 1997, Zhou et al. 2001, Nemani et al. 2003, Jia et al. 2004), which is also consistent with photographic and remote sensing analyses indicating that tundra in Alaska is becoming more shrubby (Sturm et al. 2001a, Silapaswan et al. 2001, Stow et al. 2004). Among studies that have examined the growing-season $\mathrm{CO}_{2}$ exchange of tundra ecosystems on the North Slope of Alaska over the last several decades, there appears to have been an initial release of $\mathrm{CO}_{2}$ followed by a longer term response of either decreasing source strength or increasing sink strength for atmospheric $\mathrm{CO}_{2}$ (Oechel et al. 2000a). This analysis is consistent with model results indicating that $\mathrm{R}_{\mathrm{H}}$ may potentially increase more than NPP in response to a sudden rise in temperature in the short term, but that interactions between $\mathrm{C}$ and $\mathrm{N}$ dynamics will cause NPP to increase more than $\mathrm{R}_{\mathrm{H}}$ over the long term. A time lag in the response of $\mathrm{CO}_{2}$ exchange by ecosystems to increases in temperature also agrees with the findings of Braswell et al. (1997).

Similar to the retrospective analyses of $\mathrm{CO}_{2}$ exchange over the last several decades, a key issue of the future response of $\mathrm{CO}_{2}$ exchange of Arctic tundra is whether increases in $R_{H}$ in response to rising temperature will keep pace with increases in NPP. The modeling analyses generally agree that the response of $\mathrm{R}_{\mathrm{H}}$ to temperature will be greater if soils dry in response to climate change. The analysis of Clein et al. (2000) indicated that $R_{H}$ will more likely keep pace if most of the $\mathrm{R}_{\mathrm{H}}$ flux is derived from labile carbon pools. Also, some analyses indicate that $R_{H}$ could continue to increase at a faster rate than NPP if temperature increases are sufficient to deepen soil active layers, making additional soil organic matter available for decomposition (e.g., Grant et al. 2003, see also Goulden et al. 1998). The greater rate of $R_{H}$ increase can be maintained if thawing permafrost exposes labile soil organic matter that is below the rooting zone of plants so that newly available $\mathrm{N}$ is not available for plant uptake. While some analyses on the pan-Arctic scale do consider permafrost dynamics, they do not explicitly consider the decomposition of soil organic matter that has been exposed by the thawing of permafrost and may overestimate the degree of future net storage of atmospheric $\mathrm{CO}_{2}$.

In general, retrospective analyses of $\mathrm{CH}_{4}$ exchange during the last several decades indicate that net methane emissions are increasing in response to rising temperature because of the sensitivity of methanogenesis to rising soil temperatures. The simulated increase in methane emissions by process-based models over this period is consistent with changes in the atmospheric concentration of methane in recent decades and with atmospheric inversions of methane dynamics (Chen 2004). The prognostic analyses of $\mathrm{CH}_{4}$ exchange also 
indicate that net methane emissions from Arctic tundra are likely to increase through the next decade primarily because the temperature sensitivity of methanogenesis more than compensates for any drops in water table depth.

To assess the net global warming effect of future $\mathrm{CO}_{2}$ and $\mathrm{CH}_{4}$ exchange the global warming potential (IPCC 2001 ) is used. On average process-based models (McGuire et al. 2000a, Callaghan 2005) estimate a mean annual $\mathrm{CO}_{2}$ uptake of $0.16 \mathrm{Pg} \mathrm{C} / \mathrm{yr}$ over the 21 st century for the Arctic. In terms of global warming potential this would balance $\mathrm{CH}_{4}$ emissions of 9 and $26 \mathrm{Tg} \mathrm{CH}_{4} / \mathrm{yr}$ based on a 20- and 100-year time horizon, respectively. Current estimates of $\mathrm{CH}_{4}$ emission from tundra ecosystems are $21 \mathrm{Tg} \mathrm{CH}_{4} / \mathrm{yr}$ (Zhuang et al. 2004), and are projected to double by 2100 (Grant et al. 2003, Gedney et al. 2004, Zhuang et al. 2004). This suggests the combined future $\mathrm{CO}_{2}$ and $\mathrm{CH}_{4}$ exchange from Arctic tundra is likely to contribute to climate warming.

Data sets that are particularly useful in ecological modeling studies include: gridded long-term climate data sets covering the pan-Arctic, data from long-term study sites representative of the different tundra ecosystems and manipulation experiments (e.g., $\mathrm{N}$ fertilization, soil warming), and decadal time series of remotely sensed data. Good quality climate data are needed to run the models. Data from long-term representative study sites and manipulation experiments are needed to calibrate models, and are important to gain process understanding and knowledge of Arctic ecosystem structure and functioning and the potential impacts of environmental change on these ecosystems. This understanding can be fed back into model process description and parametrization, and the decadal time series of high temporal and spatial fidelity remotely sensed data is important for model evaluation and further development.

A major uncertainty in the projections of both the remote sensing and process-based models that have been used to assess the responses of $\mathrm{CO}_{2}$ and $\mathrm{CH}_{4}$ exchange in Arctic tundra is that the spatial and temporal dynamics of these models have yet to be comprehensively evaluated. Most of the data used to develop and evaluate these models is limited to tundra sites in Alaska. With respect to the current generation of process-based models, we have identified three types of uncertainties associated with: the climatic variables used to drive model simulations, accurate representation of critical processes in the models, and critical processes and feedbacks that are currently unknown or not well represented by the models.

The current high-latitude meteorological station density is extremely sparse and largely limited to coastal areas. Spatially explicit climate datasets for the Arctic derived from atmospheric general circulation model (GCM) simulations have relatively coarse (0.5-3.75 degree) spatial resolutions and differ substantially depending upon the particular GCM employed in the simulation. Efforts to improve gridded data sets of historical climate conditions for the pan-Arctic would advance the ability for accurately assessing the spatial patterns of past and projected responses of regional carbon dynamics for pan-Arctic tundra in a more realistic fashion. This has enormous implications for realistic assessment of the Arctic response to future climate scenarios and the potential of the Arctic to enhance or mitigate global climate change.

Uncertainty in the depiction of the role of recalcitrant soil carbon in long-term ecosystem carbon dynamics results from our incomplete understanding of controls over carbon and nitrogen transformations in Arctic soils. Mechanistic studies of these issues are needed to improve our ability to model the response of Arctic ecosystems to global change (Clein et al. 2000). Also, the causal linkage between temperature and decomposition and nitrogen availability to plants needs to be better understood. In particular, the competition between plants and microbes for available nitrogen and nitrogen retention by tundra ecosystems needs further elucidation.

Future modeling and field studies should address a number of issues currently not well represented in models. Representation of plant functional types by the current generation of regional models is largely limited to one or two types, which is insufficient to account for the diversity in tundra ecosystems. A particular requirement is representation of mosses in regulating tundra thermal and hydrologic dynamics that influence carbon storage. Since tundra ecosystems are nitrogen limited, nitrogen fixation is an important process affecting changes in carbon storage. As yet, this process is not fully understood or adequately represented by regional models. Productivity of aquatic ecosystems tends to be limited more by phosphorous than nitrogen, but interaction between phosphorous and carbon dynamics are not included in the current generation of regional models. Topographic controls over soil moisture are generally not well represented in regional models, since models are applied at coarser spatial resolutions than the underlying topographic variability (McGuire et al. 2000a). Thus far, only Stieglitz et al. (2000) has coupled a hydrology model of lateral flow to a carbon and nitrogen model to study the effects of climate and associated hydrologic change on carbon dynamics in the Imnavait Creek subcatchment $\left(2.2 \mathrm{~km}^{2}\right)$ of the Kuparuk river basin of Alaska. Heterogeneity in surface hydrology that affects carbon dynamics occurs at resolutions on the order of meters. Scaling this variability to resolutions considered by regional models represents a major challenge.

Drainage and permafrost condition largely control the spatial extent and distribution of tundra wetlands, and the production of $\mathrm{CH}_{4}$ (Christensen et al. 2004). Permafrost, its dynamics, and disturbance are crucial in shaping the Arctic landscape and its heterogeneity, e.g., on the short time scale, thermokarst lakes can be 
formed as frozen soil water melts, causing local subsidence and flooding. However, depending on the groundwater level, permafrost degradation can also lead to long-term regional surface drying, with surface water now able to infiltrate lower soil horizons and access groundwater. Increased drainage associated with permafrost degradation is largely responsible for decreasing area of ponds on the Seward Peninsula of Alaska over the last 50 years (Stow et al. 2004, Hinzman et al. 2005). Sufficient representation of permafrost and soil drainage will improve model predictions of the response of wetland carbon dynamics to current and future patterns of climate change. Permafrost and active-layer dynamics are now being developed and incorporated into regional models (Zhuang et al. 2001, 2003), but the coupling of these dynamics to hydrological processes is rudimentary and needs greater sophistication. An important issue is the fate of soil organic carbon that is exposed by the thawing of permafrost, an issue that is not considered in most models and is difficult to represent at the scale of the pan-Arctic. Also, it is clear that fire is currently an important disturbance in Siberian tundra and may increase in regional extent, frequency, and severity in the Arctic under warmer climate conditions, but is currently not adequately represented in regional models. Increases in fire frequency have the potential to rapidly release large quantities of soil carbon.

The recent launch of multiple sensors onboard individual satellite platforms, such as NASA's EOS Terra and Aqua satellites, and efforts to improve integration and coordination of these data within public data archives will likely continue to improve satellite remote sensing capabilities for regional detection, monitoring and evaluation of pan-Arctic carbon cycle dynamics.

\section{Conclusions}

Remote sensing observations indicate a general greening trend and increased vegetation productivity in Arctic tundra ecosystems over recent decades. Modeling studies suggest a small net exchange of $\mathrm{CO}_{2}$ between the tundra and atmosphere during the present-day and recent past with large interannual and spatial variability in the exchange of $\mathrm{CO}_{2}$. Process-based studies indicate that the Arctic will be a small sink of atmospheric $\mathrm{CO}_{2}$ during the next 100 years. However, increasing emissions of methane in response to rising soil temperatures will likely lead to the Arctic being a future source of greenhouse gases. Key uncertainties in our current understanding of Arctic carbon cycle dynamics involve: (1) the role of fire; (2) the potential responses of NPP and $R_{H}$ to temperature and moisture interactions, deepening soil active layers and the role of soil nutrients $(\mathrm{N}, \mathrm{P})$ in mitigating or enhancing these responses; (3) the relative accuracy of regional climatic drivers used for process model simulations; (4) model representation of soil hydrologic processes and potential soil moisture response to climate change; and (5) changes in the areal extent and distribution of wetlands.
ACKNOWLEDGMENTS

We thank the two anonymous reviewers for their suggestions on improving this manuscript. This research was a product of meetings supported by the FATE project under the International Arctic Science Committee and the National Science Foundation through the International Arctic Research Centre in Fairbanks. Nicola Gedney was supported by the U.K. Department for Environment, Food and Rural Affairs under the Climate Prediction Programme PECD/7/12/37. Portions of this work, relating to change in spring thaw date analysis, were performed at the Jet Propulsion Laboratory, California Institute of Technology, under contract to the National Aeronautics and Space Administration.

\section{Literature Cited}

Armstrong, R. L., and M. J. Brodzik. 2001. Recent Northern Hemisphere snow extent: a comparison of data derived from visible and microwave sensors. Geophysical Research Letters 28:3673-3676.

Aselmann, I., and P. J. Crutzen. 1989. Global distribution of natural freshwater wetlands and rice paddies, their net primary productivity, seasonality and possible methane emissions. Journal of Atmospheric Chemistry 8:307-358.

Asrar, G., M. Fuchs, E. T. Kanemasu, and J. L. Hatfield. 1984. Estimating absorbed photosynthetic radiation and leaf area index from spectral reflectance in wheat. Agronomy Journal 76:300-306.

Boles, S. H., and D. L. Verbyla. 1999. Effect of scan angle on AVHRR fire detection accuracy in interior Alaska. International Journal of Remote Sensing 20:3437-3443.

Bowling, L. C., D. L. Kane, R. E. Gieck, L. D. Hinzman, and D. P. Lettenmaier. 2003. The role of surface storage in a lowgradient Arctic watershed. Water Resources Research 39(4): 1087. [doi: 10.1029/2002WR001466]

Braswell, B. H., D. S. Schimel, E. Linder, and B. Moore, III. 1997. The response of global terrestrial ecosystems to interannual temperature variability. Science 278:870-872.

Callaghan, T. V., et al. 2004. Climate change and UV-B impacts on arctic tundra and polar desert ecosystems: effects of changes in climate on landscape and regional processes, and feedbacks to the climate system. Ambio 33(7):459-468.

Callaghan, T. V., et al. 2005. Arctic tundra and polar desert ecosystems. Pages 243-352 in Arctic climate impact assessment (ACIA). Cambridge University Press, Cambridge, UK.

Cao, M. K., K. Gregson, and S. Marshall. 1998. Global methane emission from wetlands and its sensitivity to climate change. Atmospheric Environment 32:3293-3299.

Cao, M. K., S. Marshall, and K. Gregson. 1996. Global carbon exchange and methane emissions from natural wetlands: application of a process-based model. Journal of Geophysical Research: Atmospheres 101(D9):14399-14414.

Chapman, W. L., and J. E. Walsh. 1993. Recent variations of sea ice and air temperature in high latitudes. Bulletin of the American Meteorological Society 74:2-16.

Chen, Y. 2004. Estimation of methane and carbon dioxide surface fluxes using a 3-D global atmospheric chemical transport model. Dissertation. Massachusetts Institute of Technology, Boston, Massachusetts, USA.

Christensen, T. R., T. Johansson, H. J. Åkermann, M. Mastepanov, N. Malmer, T. Friborg, P. Crill, and B. H. Svensson. 2004. Thawing sub-Arctic permafrost: effects on vegetation and methane emissions. Geophysical Research Letters 31:L04501. [doi:10.1029/2003GL018680]

Cihlar, J., J. M. Chen, Z. Li, F. Huang, R. Latifovic, and R. Dixon. 1998. Can interannual land surface signal be discerned in composite AVHRR data? Journal of Geophysical Research-Atmospheres 103(D18):23163-23172.

Clein, J. S., B. Kwiatkowski, A. D. McGuire, J. E. Hobbie, E. B. Rastetter, J. M. Melillo, and D. W. Kicklighter. 2000. Modelling carbon responses of tundra ecosystems to 
historical and projected climate: a comparison of a plot- and a global-scale ecosystem model to identify process-based uncertainties. Global Change Biology 6:127-140.

Collatz, G. J., M. Ribas-Carbo, and J. A. Berry. 1992. A coupled photosynthesis-stomatal conductance model for leaves of C4 plants. Australian Journal of Plant Physiology 19:519-538.

Comer, N. T., P. M. Lafleur, N. T. Roulet, M. G. Letts, M. Skarupa, and D. Verseghy. 2000. A test of the Canadian land surface scheme (CLASS) for a variety of wetland types. Atmosphere Ocean 38:161-179.

Comiso, J. C. 2003. Warming trends in the Arctic from clear sky satellite observations. Journal of Climate 16(21):34983510.

Dye, D. G., and C. J. Tucker. 2003. Seasonality and trends of snow-cover, vegetation index, and temperature in northern Eurasia. Geophysical Research Letters 30(7):1405. [doi:10. 1029/2002GL016384]

Entekhabi, D., et al. 2004. The hydrosphere state (HYDROS) mission: an Earth system pathfinder for global mapping of soil moisture and land freeze/thaw. IEEE Transactions in Geoscience and Remote Sensing 42(10):2184-2195.

Farquhar, G. D., and S. von Caemmerer. 1982. Modelling of photosynthetic response to the environment. Pages 549-587 in O. L. Lange, P. S. Nobel, C. B. Osmond, and H. Ziegler, editors. Physiological plant ecology II. Encyclopedia of plant physiology. New Series. Volume 12B. Springer-Verlag, Berlin, Germany.

Farquhar, G. D., S. von Caemmerer, and J. A. Berry. 1980. A biochemical model of photosynthetic $\mathrm{CO}_{2}$ assimilation in leaves of $\mathrm{C}_{3}$ species. Planta 149:78-90.

Foley, J. A. 1995. An equilibrium model of the terrestrial carbon budget. Tellus 47(B):310-319.

Friborg, T., H. Soegaard, T. R. Christensen, C. R. Lloyd, and N. S. Panikov. 2003. Siberian wetlands: where a sink is a source. Geophysical Research Letters 30(21):2129. [doi:10.1029/2003GL017797]

Frolking, S., K. C. McDonald, J. S. Kimball, J. B. Way, R. Zimmermann, and S. W. Running. 1999. Using the spaceborne NASA scatterometer (NSCAT) to determine the frozen and thawed seasons of a boreal landscape. Journal of Geophysical Research 104(D22):27895-27907.

Gedney, N., and P. M. Cox. 2003. The sensitivity of global climate model simulations to the representation of soil moisture heterogeneity. Journal of Hydrometeorology 4:1265-1275.

Gedney, N., P. M. Cox, and C. Huntingford. 2004. Climate feedback from wetland methane emissions. Geophysical Research Letters 31:L20503. [doi:10.1029/2004GL020919]

Gould, W. A., S. Edlund, S. Zoltai, M. Raynolds, D. A. Walker, and H. Maier. 2002. Canadian Arctic vegetation mapping. International Journal of Remote Sensing 23:4597-4609.

Goulden, M. L., et al. 1998. Sensitivity of boreal forest carbon balance to soil thaw. Science 279:214-217.

Grant, R. F. 2001. A review of the Canadian ecosystem model ecosys. Pages 173-263 in M. Shaffer, editor. Modeling carbon and nitrogen dynamics for soil management. CRC Press, Boca Raton, Florida, USA.

Grant, R. F., W. C. Oechel, and C.-L. Ping. 2003. Modelling carbon balances of coastal Arctic tundra under changing climate. Global Change Biology 9:16-36.

Groisman, P. Y., T. R. Karl, and R. W. Knight. 1994. Observed impact of snow cover on the heat balance and rise of continental spring temperatures. Science 263:198-200.

Gutman, G. G. 1999. On the monitoring of land surface temperatures with the NOAA/AVHRR: removing the effect of satellite orbit drift. International Journal of Remote Sensing 20(17):3407-3413.

Gutman, G., and A. Ignatov. 1995. Global land monitoring from AVHRR: potential and limitations. International Journal of Remote Sensing 16(13):2301-2309.
Hinzman, R. D., et al. 2005. Evidence and implications of recent climate change in northern Alaska and other Arctic regions. Climatic Change 72:251-298.

Hinzman, L. D., D. J. Goering, and D. L. Kane. 1998. A distributed thermal model for calculating soil temperature profiles and depth of thaw in permafrost regions. Journal of Geophysical Research 103(D22):28975-28991.

Hinzman, L. D., K. Yoshikawa, and D. L. Kane. 2001. Hydrologic response and feedbacks to a warmer climate in Arctic regions. Proceedings of the second Wadati conference on global change and polar climate, 7-9 March 2001, Tsukuba, Japan.

Hobbie, J. E., B. L. Kwiatkowski, E. B. Rastetter, D. A. Walker, and R. B. McKane. 1998. Carbon cycling in the Kuparuk River Basin: plant production, carbon storage, and sensitivity to future changes. Journal of Geophysical Research 103(D22):29065-29073.

Hope, A. S., W. L. Boynton, D. A. Stow, and D. C. Douglas. 2003. Interannual growth dynamics of vegetation in the Kuparuk river watershed, Alaska, based on the Normalized Difference Vegetation Index. International Journal of Remote Sensing 24:3413-3425.

IPCC [Intergovernmental Panel on Climate Change]. 2001. Climate change 2001. The scientific basis. Contribution of Working Group I to the Third Assessment Report of the Intergovernmental Panel on Climate Change. J. T. Houghton, Y. Ding, D. J. Griggs, M. Noguer, P. J. van der Linden, X. Dai, K. Maskell, and C. A. Johnson, editors. Cambridge University Press, Cambridge, UK.

Jia, G. J., H. E. Epstein, and D. A. Walker. 2004. Controls over intra-seasonal dynamics of AVHRR NDVI for the Arctic tundra in northern Alaska. International Journal of Remote Sensing 25:1547-1564.

Kane, D. L., L. D. Hinzman, Y. Haofang, and D. J. Goering. 1996. The use of SAR satellite imagery to measure active layer moisture contents in Arctic Alaska. Nordic Hydrology 27(1-2):25-38.

Kaplan, J. O. 2002. Wetlands at the last glacial maximum: distribution and methane emissions. Geophysical Research Letters 29(6):1079. [doi:10.1029/2001GL013366]

Kimball, J. S., K. McDonald, A. R. Keyser, S. Frolking, and S. W. Running. 2001. Application of the NASA Scatterometer (NSCAT) for determining the daily frozen and nonfrozen landscape of Alaska. Remote Sensing of Environment 75:113-126.

Kimball, J. S., K. C. McDonald, S. W. Running, and S. E. Frolking. 2004. Satellite radar remote sensing of seasonal growing seasons for boreal and subalpine evergreen forests. Remote Sensing of Environment 90:243-258.

Krinner, G. 2003. Impact of lakes and wetlands on boreal climate. Journal of Geophysical Research 108(D16):4520. [doi:10.1029/2002JD002597]

Lal, R., and J. M. Kimble. 2000. Soil C pool and dynamics in cold ecoregions. Pages 3-28 in R. Lal, J. M. Kimble, and B. A. Stewart, editors. Global climate change and cold region ecosystems. CRC Press LLC/Lewis Publishing, Boca Raton, Florida, USA.

Le Dizès, S., B. L. Kwiatkowski, E. B. Rastetter, A. Hope, J. E. Hobbie, D. Stow, and S. Daeschner. 2003. Modeling biogeochemical responses of tundra ecosystems to temporal and spatial variations in climate in the Kuparuk River Basin (Alaska). Journal of Geophysical Research 108(D2):8165. [doi:10.1029/2001JD000960]

Letts, M. G., N. T. Roulet, N. T. Comer, M. R. Skarupa, and D. L. Verseghy. 2000. Parametrization of peatland hydraulic properties for the Canadian land surface scheme. Atmosphere-Ocean 38:141-160.

Lloyd, C. R. 2001. The measurement and modelling of the carbon dioxide exchange at a high Arctic site in Svalbard. Global Change Biology 7:405-426. 
Lloyd, J., and J. A. Taylor. 1994. On the temperature dependence of soil respiration. Functional Ecology 8:315-323.

Lucht, W., I. C. Prentice, R. B. Myneni, S. Sitch, P. Friedlingstein, W. Cramer, P. Bousquet, W. Buermann, and B. Smith. 2002. Climate control of the high-latitude vegetation greening trend and Pinatubo effect. Science 296: $1687-1689$.

Malmer, N. 1992. Peat accumulation and the global carbon cycle. Pages 97-100 in M. Boer and E. Koster, editors. Greenhouse impact on cold-climate ecosystems and landscapes. Catena Verlag, Cremlingen-Destedt, Germany.

Markon, C. J., and K. M. Peterson. 2002. The utility of estimating net primary productivity over Alaska using baseline AVHRR data. International Journal of Remote Sensing 23:4571-4596.

McDonald, K. C., J. S. Kimball, E. Njoku, R. Zimmermann, and M. Zhao. 2004. Variability in springtime thaw in the terrestrial high latitudes: monitoring a major control on the biospheric assimilation of atmospheric $\mathrm{CO}_{2}$ with spaceborne microwave remote sensing. Earth Interactions 8(20):1-23.

McGuire, A. D., J. S. Clein, J. M. Melillo, D. W. Kicklighter, R. A. Meier, C. J. Vorosmarty, and M. C. Serreze. $2000 a$. Modelling carbon responses of tundra ecosystems to historical and projected climate: sensitivity of pan-Arctic carbon storage to temporal and spatial variation in climate. Global Change Biology 6:141-159.

McGuire, A. D., J. M. Melillo, L. A. Joyce, D. W. Kicklighter, A. L. Grace, B. Moore, III, and C. J. Vörösmarty. 1992. Interactions between carbon and nitrogen dynamics in estimating net primary productivity for potential vegetation in North America. Global Biogeochemical Cycles 6:101-124.

McGuire, A. D., J. M. Melillo, D. W. Kicklighter, Y. Pan, X. Xiao, J. Helfrich, B. Moore, III, C. J. Vorosmarty, and A. L. Schloss. 1997. Equilibrium responses of global net primary production and carbon storage to doubled atmospheric carbon dioxide: sensitivity to changes in vegetation nitrogen concentration. Global Biogeochemical Cycles 11:173-189.

McGuire, A. D., J. M. Melillo, J. T. Randerson, W. J. Parton, M. Heimann, R. A. Meier, J. S. Clein, D. W. Kicklighter, and W. Sauf. 2000b. Modeling the effects of snowpack on heterotrophic respiration across northern temperate and high latitude regions: comparison with measurements of atmospheric carbon dioxide in high latitudes. Biogeochemistry 48: 91-114.

McKane, R. B., E. B. Rastetter, G. R. Shaver, K. J. Nadelhoffer, A. E. Giblin, J. A. Laundre, and F. S. Chapin, III. 1997a. Climatic effects on tundra carbon storage inferred from experimental data and a model. Ecology 78:1170-1187.

McKane, R. B., E. B. Rastetter, G. R. Shaver, K. J. Nadelhoffer, A. E. Giblin, J. A. Laundre, and F. S. Chapin, III. 1997b. Reconstruction and analysis of historical changes in carbon storage in Arctic tundra. Ecology 78:1188-1198.

Myneni, R. B., F. G. Hall, P. J. Sellers, and A. L. Marshak. 1995. The interpretation of spectral vegetation indexes. IEEE Transactions on Geoscience and Remote Sensing 33:481-486.

Myneni, R. B., C. D. Keeling, C. J. Tucker, G. Asrar, and R. R. Nemani. 1997. Increased plant growth in the northern high latitudes from 1981-1991. Nature 386:698-702.

Nakićenović, N., et al. 2000. IPCC Special report on emissions scenarios. Cambridge University Press, New York, New York, USA.

Nemani, R. R., C. D. Keeling, H. Hashimoto, W. M. Jolly, S. C. Piper, C. J. Tucker, R. B. Myneni, and S. W. Running. 2003. Climate-driven increases in global terrestrial net primary production from 1982 to 1999 . Science 300:1560-1563.

New, M., M. Hulme, and P. D. Jones. 1999. Representing twentieth-century space-time climate variability. Part I: development of a 1961-90 mean monthly terrestrial climatology. Journal of Climate 12:829-856.

Oechel, W. C., S. J. Hastings, G. Vourlitis, M. Jenkins, G. Riechers, and N. Grulke. 1993. Recent change of Arctic tundra ecosystems from a net carbon dioxide sink to a source. Nature 361:520-523.

Oechel, W. C., G. L. Vourlitis, S. J. Hastings, R. C. Zulueta, L. Hinzman, and D. Kane. 2000a. Acclimation of ecosystem $\mathrm{CO}_{2}$ exchange in Alaskan Arctic in response to decadal climate warming. Nature 406:978-981.

Oechel, W. C., et al. $2000 \mathrm{~b}$. A scaling approach for quantifying the net $\mathrm{CO}_{2}$ flux of the Kuparuk River Basin, Alaska. Global Change Biology 6:160-173.

Prather, M., et al. 2001. Atmospheric chemistry and greenhouse gases. Pages 240-287 in J. T. Houghton, Y. Ding, D. J. Griggs, M. Noguer, P. J. van der Linden, X. Dai, K. Maskell, and C. A. Johnson, editors. Climate change 2001: the scientific basis. Contribution of Working Group I to the Third Assessment Report of the Intergovernmental Panel on Climate Change. First edition. Cambridge University Press, Cambridge, UK.

Pulliainen, J., and M. Hallikainen. 2001. Retrieval of regional snow water equivalent from space-borne passive microwave observations. Remote Sensing of Environment 75:76-85.

Ranson, K. J., and G. Sun. 2000. Effects of environmental conditions on boreal forest classification and biomass estimates with SAR. IEEE Transactions on Geoscience and Remote Sensing 38:1242-1252.

Ranson, K. J., G. Sun, R. Lang, N. S. Chauhan, R. J. Cacciola, and O. Kilic. 1997. Mapping of boreal forest biomass from spaceborne synthetic aperture radar. Journal of Geophysical Research 102(D24):29599-29610.

Rastetter, E. B., B. L. Kwiatkowski, S. Le Dizès, and J. E. Hobbie. 2004. The role of down-slope water and nutrient fluxes in the response of Arctic hill slopes to climate change. Biogeochemistry 69:37-62.

Rastetter, E. B., R. B. McKane, G. R. Shaver, K. J. Nadelhoffer, A. E. Giblin, J. A. Laundre, and F. S. Chapin, III. 1997. Analysis of $\mathrm{CO}_{2}$, temperature and moisture effect on carbon storage in Alaskan Arctic tundra using a general ecosystem model. Pages 437-451 in W. C. Oechel, T. Callaghan, T. Gilmanov, J. I. Holten, B. Maxwell, U. Molau, and B. Sveinbjornsson, editors. Global change and arctic terrestrial ecosystems (Ecological Studies 124). Springer-Verlag, New York, New York, USA.

Running, S. W., R. R. Nemani, F. A. Heinsch, M. Zhao, M. Reeves, and H. Hashimoto. 2004. A continuous satellitederived measure of global terrestrial primary production. BioScience 54:547-560.

Running, S. W., P. E. Thornton, R. R. Nemani, and J. M. Glassy. 2000. Global terrestrial gross and net primary productivity from the earth observing system. Pages 44-57 in O. Sala, R. Jackson, and H. Mooney, editors. Methods in ecosystem science. Springer-Verlag, New York, New York, USA.

Serreze, M. C., D. H. Bromwich, M. P. Clark, A. J. Etringer, T. Zhang, and R. Lammers. 2003. Large-scale hydro-climatology of the terrestrial Arctic drainage system. Journal of Geophysical Research 108(D2):8160. [doi:10.1029/ 2001JD000919]

Serreze, M. C., J. E. Walsh, F. S. Chapin, III, T. Osterkamp, M. Dyurgerov, V. Romanovsky, W. C. Oechel, J. Morison, T. Zhang, and R. G. Barry. 2000. Observational evidence of recent change in the northern high-latitude environment. Climatic Change 46:159-207.

Shaver, G. R., W. D. Billings, F. S. Chapin, III, A. E. Giblin, K. J. Nadelhoffer, W. C. Oechel, and E. B. Rastetter. 1992. Global change and the carbon balance of Arctic ecosystems. Bioscience 42:433-441.

Silapaswan, C. S., D. L. Verbyla, and A. D. McGuire. 2001. Land cover change on the Seward Peninsula: the use of remote sensing to evaluate the potential influences of climate warming on historical vegetation dynamics. Canadian Journal of Remote Sensing 27(5):542-554. 
Sitch, S., et al. 2003. Evaluation of ecosystem dynamics, plant geography and terrestrial carbon cycling in the LPJ dynamic global vegetation model. Global Change Biology 9:161-185.

Soegaard, H., C. Nordstroem, T. Friborg, B. U. Hansen, T. R. Christensen, and C. Bay. 2000. Trace gas exchange in a highArctic valley 3 . Integrating and scaling $\mathrm{CO}_{2}$ fluxes from canopy to landscape using flux data, footprint modeling, and remote sensing. Global Biogeochemical Cycles 14(3):725744.

Stieglitz, M., A. Giblin, J. Hobbie, M. Williams, and G. Kling. 2000. Simulating the effects of climate change and climate variability on carbon dynamics in Arctic tundra. Global Biogeochemical Cycles 14:1123-1136.

Stone, R. S., E. G. Dutton, J. M. Harris, and D. Longenecker. 2002. Earlier spring snowmelt in northern Alaska as an indicator of climate change. Journal of Geophysical Research 107(D10):4089. [doi:10.1029/2000JD000286]

Stow, D. A., et al. 2004. Remote sensing of vegetation and landcover change in Arctic tundra ecosystems. Remote Sensing of Environment 89:281-308.

Sturm, M., C. Racine, and K. Tape. 2001. Increasing shrub abundance in the Arctic. Nature 411:546-547.

Thonicke, K., S. Venevsky, S. Sitch, and W. Cramer. 2001. The role of fire disturbance for global vegetation dynamics: coupling fire into a Dynamic Global Vegetation Model. Global Ecology and Biogeography 10:661-677.

Tucker, C. J. 1979. Red and photographic infrared linear combinations for monitoring vegetation. Remote Sensing Environment 8:127-150.

Tucker, C. J., and P. J. Sellers. 1986. Satellite remote sensing of primary production. International Journal of Remote Sensing 7:1395-1416.

Ulaby, F. T., R. K. Moore, and A. K. Fung. 1986. Microwave remote sensing: active and passive. Volume 1: Fundamentals and radiometry. Artec House, Dedham, Massachusetts, USA.

Van Wijk, M. T., M. Williams, J. A. Laundre, and G. R. Shaver. 2003. Interannual variability of plant phenology in tussock tundra: modelling interactions of plant productivity, plant phenology, snowmelt and soil thaw. Global Change Biology 9:743-758.

Vlassova, T. K. 2002. Human Impacts on the tundra-taiga zone dynamics: the case of the Russian lesotundra. Ambio Special Report (Tundra-Taiga Treeline Research) 12:30-36.

Walker, D. A., et al. 2003. Phytomass, LAI, and NDVI in northern Alaska: relationships to summer warmth, soil $\mathrm{pH}$, plant functional types, and extrapolation to the circumpolar Arctic. Journal of Geophysical Research 108(D2):8169. [doi:80.1029/2001JD000986]

Walker, D. A., W. A. Gould, H. A. Maier, and M. K. Raynolds. 2002. The circumpolar arctic vegetation map: AVHRR-derived base maps, environmental controls, and integrated mapping procedures. International Journal of Remote Sensing 23:4551-4570.

Walter, B. P., M. Heimann, and E. Matthews. 2001a. Modeling modern methane emissions from natural wetlands 1 . Model description and results. Journal of Geophysical Research 106(D24):34189-34206.

Walter, B. P., M. Heimann, and E. Matthews. 2001b. Modeling modern methane emissions from natural wetlands 2 . Inter- annual variations 1982-1993. Journal of Geophysical Research 106(D24):34207-34219.

Williams, M., W. Eugster, E. B. Rastetter, J. P. McFadden, and F. S. Chapin, III. 2000. The controls on net ecosystem productivity along an Arctic transect: a model comparison with flux measurements. Global Change Biology 6:116126.

Williams, M., B. E. Law, P. M. Anthoni, and M. H. Unsworth. 2001a. Use of a simulation model and ecosystem flux data to examine carbon-water interactions in ponderosa pine. Tree Physiology 21:287-298.

Williams, M., E. B. Rastetter, D. N. Fernandes, M. L. Goulden, S. C. Wofsy, G. R. Shaver, J. M. Melillo, J. W. Munger, S.-M. Fan, and K. J. Nadelhoffer. 1996. Modelling the soil-plant-atmosphere continuum in a Quercus-Acer stand at Harvard forest: the regulation of stomatal conductance by light, nitrogen and soil/plant hydraulic properties. Plant Cell Environment 19:911-927.

Williams, M., E. B. Rastetter, G. R. Shaver, J. E. Hobbie, E. Carpino, and B. L. Kwiatkowski. 2001b. Primary production of an Arctic watershed: an uncertainty analysis. Ecological Applications 11:1800-1816.

Zamolodchikov, D. G., and D. V. Karelin. 2001. An empirical model of carbon fluxes in Russian tundra. Global Change Biology 7:147-161.

Zhang, T., and R. L. Armstrong. 2001. Soil freeze/thaw cycles over snow-free land detected by passive microwave remote sensing. Geophysical Research Letters 28(5):763-766.

Zhou, L., R. K. Kaufmann, Y. Tian, R. B. Myneni, and C. J. Tucker. 2003. Relation between interannual variations in satellite measures of northern forest greenness and climate between 1982 and 1999. Journal of Geophysical Research 108(D1):4004. [doi:10.1029/2002JD002510]

Zhou, L., C. J. Tucker, R. K. Kaufmann, D. Slayback, N. V. Shabanov, and R. Myneni. 2001. Variations in northern vegetation activity inferred from satellite data of vegetation index during 1981 to 1999. Journal of Geophysical Research 106(D17):20069-20084.

Zhuang, Q., et al. 2003. Carbon cycling in extratropical terrestrial ecosystems of the Northern Hemisphere during the 20th century: a modeling analysis of the influences of soil thermal dynamics. Tellus 55B:751-776.

Zhuang, Q., J. M. Melillo, D. W. Kicklighter, R. G. Prinn, A. D. McGuire, P. A. Steudler, B. S. Felzer, and S. Hu. 2004. Methane fluxes between terrestrial ecosystems and the atmosphere at northern high latitudes during the past century: a retrospective analysis with a process-based biogeochemistry model. Global Biogeochemical Cycles 18: GB3010. [doi:10.1029/2004GB002239]

Zhuang, Q., J. M. Melillo, A. D. McGuire, D. W. Kicklighter, R. G. Prinn, P. A. Steudler, B. S. Felzer, and S. Hu. 2007. Natural methane emissions and the greenhouse gas budget for Alaska. Ecological Applications 17:203-212.

Zhuang, Q., V. E. Romanovsky, and A. D. McGuire. 2001. Incorporation of a permafrost model into a large-scale ecosystem model: Evaluation of temporal and spatial scaling issues in simulating soil thermal dynamics. Journal of Geophysical Research-Atmospheres 106(D24):3364933670 . 